Estudios Constitucionales, Año 13, No 1, 2015, pp. 271-320.

ISSN 07180195

Centro de Estudios Constitucionales de Chile Universidad de Talca

"El Recurso de Protección como control de constitucionalidad de las resoluciones y sentencias civiles, en respuesta a la ineficacia de la acción de inaplicabilidad por inconstitucionalidad"

Ignacio Ried Undurraga

\title{
EL RECURSO DE PROTECCIÓN COMO CONTROL DE CONSTITUCIONALIDAD DE LAS RESOLUCIONES Y SENTENCIAS CIVILES, EN RESPUESTA A LA INEFICACIA DE LA ACCIÓN DE INAPLICABILIDAD POR INCONSTITUCIONALIDAD*
}

\author{
The Appeal on the Grounds of Unconstitutionality as \\ CONSTITUTIONAL CONTROL OF CIVIL JUDGMENTS AND DECISIONS, IN \\ RESPONSE TO THE INEFFECTIVENESS OF THE ACTION ON INAPPLICABILITY
}

\author{
IGNACIO RIED UNDURRAGA* \\ Universidad Diego Portales \\ iried@uc.cl
}

RESUMEN: Luego de casi diez años de vigencia de la reforma constitucional del año 2005, los operadores jurídicos han advertido el acotado alcance de la acción de inaplicabilidad por inconstitucionalidad como via de tutela de los derechos fundamentalmente garantizados en el proceso civil, en especial, como control de constitucionalidad de las sentencias y actos procesales. Esto lleva a plantearse si es posible proponer al recurso de protección como una vía idónea de control de constitucionalidad respecto de las actuaciones de los tribunales civiles, propuesta que en este trabajo se afirma y justifica.

ABSTRACT: After nearly ten years of operation of the constitutional reform of 2005, the legal practitioners have realized the limited scope of the action of inapplicability as a way of protecting the rights guaranteed primarily in civil proceedings, especially as constitutional control of judgments and procedural acts. This raises the question whether it is possible to propose the appeal on the ground of unconstitutionality as a suitable way of judicial review regarding the actions of the civil courts, proposal this paper states and justifies.

PALABRAS CLAVE: recurso de protección, recurso de inaplicabilidad por inconstitucionalidad, control de constitucionalidad, proceso constitucional.

KEY WORDS: Appeal on the ground of unconstitutionality, action of inapplicability, constitutional control, constitutional procedure.

\footnotetext{
* Trabajo recibido el 18 de diciembre de 2014 y aprobado el 22 de abril de 2015.

** Abogado, licenciado en Derecho de la Pontificia Universidad Católica de Chile. Máster en Derecho penal y Ciencias penales de la Universidad de Barcelona y Universidad Pompeu Fabra, Barcelona, España. Profesor del curso de Litigación y Estrategia Civil de la Facultad de Derecho de la Universidad Diego Portales. Dirección postal: Av. Andrés Bello 2711, piso 8, comuna de Las Condes, Santiago.
} 


\section{Planteamiento del PROBlema: ineXistencia de UnA CONSAgRación} POSITIVA DEL CONTROL CONSTITUCIONAL DE LAS SENTENCIAS CIVILES

No existe en el sistema normativo chileno una consagración positiva del control de constitucionalidad de las sentencias civiles pronunciadas por los tribunales ordinarios o arbitrales, cuando en ella se vulneran las garantías fundamentales de una de las partes. Nuestro Tribunal Constitucional tiene la prerrogativa de declarar la inaplicabilidad por inconstitucionalidad de las normas de nuestro ordenamiento, siempre que existan gestiones pendientes ante un tribunal. Sin embargo, esta vía de impugnación exige como presupuesto la aplicación (efectiva o eventual) de un determinado precepto legal, que se estima inconstitucional, a los hechos del caso. Quedan, por tanto, fuera de su ámbito de protección las garantías vulneradas en la sentencia misma, en la que pudo aplicarse una norma perfectamente constitucional, pero en que el resultado de la aplicación, o la interpretación de la norma, puede ser ilegal o arbitrario. Por tanto, se produce un fenómeno indeseable en nuestro ordenamiento: la ley -creación de la voluntad soberana y democrática- puede ser invalidada por el Tribunal Constitucional, si resulta contraria a la Constitución. Sin embargo, la "ley particular para cada caso" que es la sentencia judicial civil, por regla general no puede ser invalidada, aun cuando signifique una vulneración de garantías fundamentales. Existe así una importante zona decisional sobre la que el ciudadano no tiene prerrogativa alguna para exigir un debido control de constitucionalidad.

En orden a materializar el mandato del artículo $6^{\circ}$ de la Constitución chilena, coexisten una serie de mecanismos jurisdiccionales que ejercen en algún grado controles de constitucionalidad sobre distintas normas o actos procesales. Quiero brevemente revisar cuáles son para hacer notar que ninguno de ellos permite el control constitucional de la sentencia civil misma.

Respecto de la labor jurisdiccional que ejercen los tribunales con competencia en lo civil, el Tribunal Constitucional tiene la facultad o el deber de declarar la inaplicabilidad por inconstitucionalidad de los preceptos legales u otras normas que eventualmente se apliquen concretamente a los hechos de un caso, y que se denuncien como contrarios a la Constitución, tanto por los propios tribunales como por las partes en un proceso, siempre que exista alguna gestión pendiente en el Tribunal en que esa norma pueda ser aplicada. No se anula la sentencia, sino sólo se le impide aplicarla al tribunal que conoce del caso, es decir, efectúa 
un control de normas y no de actos jurisdiccionales" ${ }^{1}$. En realidad, el control jurisdiccional de constitucionalidad está a cargo de los tribunales ordinarios, y no del Tribunal Constitucional2; así se ha dicho por la doctrina que "nuestro Tribunal Constitucional carece de facultades de control de resoluciones judiciales, pues todo lo concerniente a declarar la validez o invalidez de resoluciones y actos jurisdiccionales corresponde exclusivamente a los tribunales ordinarios (art. 76 de la Constitución)"3.

Por su parte, los tribunales de garantía pueden efectuar una cautela de garantías del imputado, cuando sus derechos fundamentales son vulnerados durante la investigación, y sobreseer temporalmente la causa (art. 10 CPP), y también conocen del recurso de amparo, contemplado en el art. 21 de la Constitución Política, en caso de una detención o prisión en que se hayan infringido estas garantías. También en materia penal, el Código Procesal Penal en su art. 373 letra a) contempla una "casación penal" (llamada nulidad en la ley) más amplia que la casación civil, ya que permite ejercer un control sobre el fallo mismo, lo mismo que la nulidad de la letra b) del mismo artículo, que es prácticamente idéntica a la casación civil, salvo por el empleo de la voz más amplia "derecho" en lugar de "ley". Asimismo, los Tribunales Tributarios y Aduaneros controlan la constitucionalidad de los "actos u omisiones" del Servicio de Impuestos Internos, a través de un procedimiento de tutela contemplado en el art. 155 del Código Tributario. Los juzgados con competencia laboral también pueden controlar la constitucionalidad de las "relaciones jurídicas cuyo conocimiento corresponde a la jurisdicción laboral”, a través de la llamada tutela laboral del art. 486 del Código del Trabajo.

1 CAzOr y PICA (2009), p. 23: "es necesario recordar que dentro de la clásica diferenciación de las ramas de la justicia constitucional planteada por Mauro Cappeletti a mediados del siglo XX y sus posteriores desarrollos, es una premisa básica distinguir las dos principales divisiones de esta disciplina: la jurisdicción constitucional de control de normas y la jurisdicción constitucional de derechos fundamentales", constatando que "en el sistema de jurisdicción constitucional chileno, el Tribunal Constitucional posee, en este orden de materias, solo facultades de control de normas, ya que no existe, por regla general, en su competencia, el amparo extraordinario de derechos fundamentales. (el destacado es mío).

2 PfefFer (2011), p. 206: "los letrados erradamente han interpretado que, al considerarse vulnerada la supremacía constitucional, la única Magistratura con competencia e idoneidad para su restablecimiento sería el Tribunal Constitucional, desconociendo que también están llamados a su tutela los tribunales con competencia para conocer de las demás acciones constitucionales, en sede de un recurso de amparo o protección, por ejemplo, o a través de los medios de impugnación que el orden legal provee: recurso de amparo económico, tutela laboral, tributaria y aduanera, recurso de nulidad penal por infracción de garantías constitucionales, entre otros".

3 Cazor y Pica (2009), pp. 23 y 24. 
Respecto de las sentencias civiles, la jurisprudencia de la Corte Suprema ha negado sistemáticamente la anulación de un fallo cuando la causal de casación es la infracción a un precepto constitucional. A este respecto, los profesores de Derecho procesal Mario Mosquera y Cristián Maturana, en su conocido Tratado sobre los recursos procesales hacen suyo el criterio de Fernando Atria, que a su vez recoge una tendencia jurisprudencial arraigada ${ }^{4}$. Aunque excede el ámbito de este trabajo, diré que no comparto esta línea jurisprudencial y doctrinaria, en aras de una adecuada defensa de los derechos fundamentales de las partes, en especial de la garantía del debido proceso, que como se verá, no es objeto del recurso de protección 5 .

Por su parte, la nulidad procesal del art. 83 del Código de Procedimiento Civil, permite atacar solamente los errores cometidos por el juzgador que producen sus efectos al interior del proceso (errores in procedendo $\sigma^{6}$ ), siempre que ese error tenga su causa en la omisión o vulneración de ciertas formas procesales. En este sentido,

4 Mosquera y Maturana (2010), pp. 295 y 296, citando a Atria (2005), pp. 284 y 285. La idea que subyace a la postura de estos autores es que la ley-que no ha sido declarada inconstitucional- es prima facie una norma constitucional, es decir, a través de ella se materializa algún principio acorde con la Carta Fundamental. Por lo tanto, y según esta postura, si el tribunal aplica la ley, no podría contravenirse la Constitución. Así, SiLva (2010), p. 487: "por lo normal, el juicio gira en torno a una correcta interpretación de la ley, operación cuyo resultado determina la existencia o inexistencia de la infracción constitucional", lo que encontraría su causa en "la necesaria proyección legal de los principios constitucionales de legalidad y tipicidad". BORDALí (2007), pp. 529530: "la idea de que la Corte Suprema pueda controlar la interpretación constitucional vía recurso de casación en el fondo ha sido constantemente rechazada por la misma Corte. Y esa posición es correcta". Ha dicho que esta postura no sólo se sustenta en razones de texto (el artículo 767 CPC sólo se refiere a infracciones de ley), sino también porque, "se pierde todo el sentido histórico de la casación considerando a la norma constitucional como objeto del recurso de casación. La casación es parte del sistema de defensa del orden democrático. Se trata que la voluntad del pueblo no sea alterada por la decisión particular de un juez". Dice este autor que las normas legales gozan de "densidad normativa", lo que no ocurre con los principios constitucionales, donde "determinar el correcto sentido de la norma constitucional termina siendo un puro acto de deliberación política dada en este caso por un órgano (Corte Suprema) que carece de legitimidad democrática".

5 Nieva (2003), pp. 169-170, a propósito de la modificación del año 2000 de la Ley de Enjuiciamiento Civil española, es de la idea que la casación por infracción a la garantía del debido proceso -invocando directamente la Constitución española- cabe "no sólo [respecto] de las sentencias que se dicten en el procedimiento especial para la tutela de los derechos fundamentales, sino en cualquier otro proceso civil en que se infrinja alguno de estos derechos (...) siempre será mejor que el Tribunal Supremo pueda desplegar su función casacional para un mayor número de supuestos".

6 Pozo (2008), p. 5 señala a propósito de los errores in procedendo que tanto el juez como las partes "pueden cometer errores por falta de observancia de las formas de la ley procesal que ha determinado en cada caso o acto y que están establecidos, como garantía para el o los justiciables en beneficio de principios que informan y son base fundamental del proceso". En la p. 11 el autor distingue estos errores de los errores in iudicando, cuya forma de subsanación es a través de los recursos procesales. 
ciertos actos jurídico-procesales que vulneran derechos fundamentalmente garantizados son también anulables procesalmente; pero no todos los actos que amagan el ejercicio de las garantías fundamentales adolecen de defectos de formas que los hagan procesalmente nulos, por aplicación estricta del referido artículo 83 . El ejemplo más evidente será una sentencia definitiva -destinada a producir sus efectos fuera del proceso- que no adolece de defectos de forma, pero sí es gravosa para las garantías de una parte o de un tercero. Asimismo, existe cierto consenso en que la nulidad de derecho público del inciso tercero del artículo $7^{\circ}$ de la Constitución no es la forma idónea de atacar una resolución judicial, principalmente por el criterio de especialidad de que gozan los recursos procesales y demás vías de impugnación, con preferencia respecto de esta nulidad, que parece reservada a los actos de la administración. Lo anterior, sin perjuicio de las profundas diferencias que existen entre la función desplegada por la administración y la función jurisdiccional, en tanto sólo las sentencias de esta última gozan de efecto de cosa juzgada, aun adoleciendo de vicios de nulidad que no fueron subsanados, lo que no sucede en el caso de los actos o resoluciones administrativas -aun firmes-, para quien está reservada esta especial nulidad por causales taxativas. Por lo demás, la nulidad de derecho público no abarca todas las hipótesis de vulneraciones que el recurso de protección cubre, sino sólo las hipótesis del referido art. 7º (actuaciones emanadas de órganos no investidos regularmente, que actúan fuera de su competencia o ilegalmente) ${ }^{7}$. Como se verá en la jurisprudencia analizada, las sentencias vulneradoras de derecho no adolecían de estos defectos.

En este trabajo se examinará el control constitucional que las Cortes de Apelaciones y la Corte Suprema han hecho de las sentencias civiles por la vía

\footnotetext{
7 ROMERo (2012), p. 256: "La sentencia judicial no está sometida al régimen de impugnación que nuestro sistema admite para declarar la nulidad de un instrumento público o de un contrato suscrito bajo esa formalidad o solemnidad. La escritura pública, una vez concluida no goza de la presunción de verdad que se atribuye a la cosa juzgada. En cambio, una vez que un fallo queda firme y produce cosa juzgada material, el único medio para revertir su eficacia es la acción de revisión, siempre que esté fundada en alguna de las causales del art. 810 del CPC. Si ello no acontece, la decisión no se puede modificar, salvo que la ley expresamente prevea un régimen especial o se haya configurado una hipótesis de cosa juzgada aparente, que pueda ser removida a través de algunos de los instrumentos que admite el ordenamiento jurídico. A lo anterior se debe adicionar la improcedencia de la acción de nulidad de derecho público para impugnar resoluciones judiciales, atendido que el proceso jurisdiccional cuenta con un mecanismo exclusivo y excluyente de impugnación: el sistema de recursos procesales". En el mismo sentido, Romero (2003) quien analiza un interesante fallo de la Corte Suprema del año 2000, que rechazó una nulidad de derecho público solicitada por los trabajadores de la empresa textil Machasa respecto de una sentencia (irrecurrible) que a su vez había rechazado un recurso de revisión. Sobre las notas distintivas de la jurisdicción, cuya principal característica es gozar sus sentencias del efecto de cosa juzgada, ver SERRA (2008), pp. 52-53.
} 
del recurso de protección, en el ejercicio del amplísimo mandato del art. 20 de la Constitución, que le permite a estos tribunales ordinarios, "adoptar de inmediato las providencias que juzgue necesarias para restablecer el imperio del derecho", entre las cuales está la invalidación de un fallo judicial, siempre que exista un "acto $u$ omisiones arbitrarios o ilegales" 8 que causen una "privación, perturbación o amenaza en el legítimo ejercicio de los derechos y garantías" constitucionales ${ }^{9}$. Como podrá notar el lector, el artículo 20 de la Constitución chilena no consagra expresamente el control constitucional de las sentencias civiles, pronunciadas por los tribunales ordinarios y arbitrales. Esta falta de reconocimiento expreso ha tenido como consecuencia interpretaciones dispares y contradictorias acerca del alcance de este recurso, como se expondrá en este trabajo.

En este panorama, los grandes perjudicados son los afectados por una vulneración de garantías cometido en las sentencias civiles, las que carecen de un control expreso de constitucionalidad. Así será, al menos hasta que entre en vigencia el llamado "recurso extraordinario" contemplado en el proyecto de Código Procesal Civil, en su art. 409 letra a), "cuando se hubiere infringido en forma esencial, en la sentencia o en el procedimiento del cual ella emanare, un derecho o garantía fundamental contemplado en la Constitución Política de la República o en los tratados internacionales ratificados por Chile y que se encuentren vigentes".

\section{El LIMITADO ALCANCE DE LA ACCIÓN DE INAPLICABILIDAD POR INCONSTITUCIONALIDAD}

Existen muchos estudios acerca de los síntomas del "fracaso" de la inaplicabilidad por inconstitucionalidad, que se adentran en las causas inmediatas -diseño institucional inadecuado, entre otras- ${ }^{10}$, pero no existe un análisis

8 Silva (2010), p. 486, anota que el control de constitucionalidad que hacen las Cortes de Apelaciones a través del recurso de protección es un control mediatizado, a través de la ley: "sólo procedería el recurso de protección contra acciones u omisiones ilegales, que no inconstitucionales. Contra esta interpretación están quienes conciben el término legal en sentido amplio, como sinónimo de infracción normativa".

9 También existe el "hermano pequeño" del recurso de protección, el recurso de amparo económico creado en la ley No 18.971. Es también competencia de las Cortes de Apelaciones, aunque es de poca recurrencia práctica, y prácticamente desconocido en el foro.

10 Respecto de las cifras concretas y las estadísticas del Tribunal Constitucional referidas al efecto que han tenido sus fallos en los procesos ordinarios en que se han pronunciado, valga el muy completo estudio de Gómez (2013), que evidencia que la influencia del Tribunal Constitucional es más bien la excepción que la regla. Sólo por dar un ejemplo del cuadro desolador del efecto que han tenido las inaplicabilidades declaradas por el Tribunal Constitucional entre 2005 y 2013, baste revisar el cuadro resumen que el autor 
decididamente procesal que permita ilustrar a los litigantes y jueces ordinarios acerca de las causas sistémicas de su actual irrelevancia al interior del proceso. La razón que explica esta intrascendencia práctica de las decisiones del Tribunal Constitucional en el marco del proceso, es que su control constitucional se produce ex ante, respecto de normas que se han aplicado en alguna etapa del proceso, o eventualmente se aplicarán, pero que no tienen necesariamente influencia determinante respecto de la sentencia de término del caso, en la que el juez ordinario sigue teniendo la última palabra. El control de constitucionalidad a cargo del Tribunal Constitucional no se ejerce respecto de las sentencias mismas, o al menos, no respecto de la sentencia de término del caso del que conoce el juez ordinario. En realidad, la situación es justo la opuesta: para recurrir al Tribunal Constitucional debe existir necesariamente una "gestión pendiente". Por tanto, sería inviable e improcedente recurrir respecto de un fallo pronunciado por la Corte Suprema, no susceptible de ulteriores recursos, o sea, en que no haya gestiones pendientes.

Por tanto, el Tribunal Constitucional no hace un control ex post de las sentencias emanadas de otros tribunales, sino que su rol consiste en decirle al juez ordinario que en las sentencias que dicte de ahora en adelante no podrá aplicar determinada norma legal, por ser contraria a la Constitución. El Tribunal Constitucional entonces, no está llamado a calificar la constitucionalidad de una sentencia, sino sólo a inaplicar una determinada norma que eventual o posiblemente el juez ordinario aplicará ${ }^{11}$. Como es natural, el juez ordinario puede fallar en forma autónoma, con la única limitante de no aplicar la norma declarada inconstitucional por el Tribunal Constitucional. Pero puede llegar perfectamente a una solución tan o más injusta que la se habría producido de haber aplicado la norma contraria a la Constitución. Esto ha sucedido muchas veces, como ha quedado plasmado en la jurisprudencia que se ha acumulado en estos casi diez años de funcionamiento. El Tribunal Constitucional obtiene en

incluye respecto del artículo 38 ter de la ley No 18.933 que regula la tabla de factores para los contratos que suscriben los afiliados a las Isapres. De 56 casos que cita el autor, en que se acogió la inaplicabilidad, en 36 casos dice que el fallo del Tribunal Constitucional no produjo efecto alguno en el juicio principal (en ese caso, un recurso de protección).

11 Dice Garrote (2012), pp. 403-404: "no existe una debida correspondencia entre la judicatura ordinaria y la jurisdicción constitucional. El tribunal a quo al resolver el juicio de fondo en caso alguno hace alusión en los considerandos de su fallo, a las consideraciones adoptadas por el Tribunal Constitucional en sus sentencias (...) el Tribunal Constitucional no está facultado para señalarle al tribunal a quo qué norma debe aplicar, sólo le puede indicar en virtud de la sentencia estimatoria de inaplicabilidad, qué norma no deberá aplicar". 
muchos casos un "triunfo moral" de que el juez ordinario no aplicó la norma que él estimó como contraria a la Constitución. Pero esto no sirve de nada, si al final la parte en el proceso sufre de la misma arbitrariedad que se trataba de evitar. Esta particular y restringida competencia ex ante es la explicación del fracaso del Tribunal Constitucional como supuesto "guardián de la Constitución”. Luis Alejandro Silva ha sido particularmente crítico del trabajo de Francisco Vega y Francisco Zúniga, quienes calificaron en su momento al "nuevo" Tribunal Constitucional como uno de "super casación"12; hoy ese calificativo "super casatorio" aparece como ingenuo o derechamente equivocado, como se expondrá más adelante.

Luis Alejandro Silva ha dicho que, "las sentencias de inaplicabilidad son inútiles". Uno de los ejemplos que da, en lo que me interesa en este trabajo, es la inutilidad de las sentencias que declaran inaplicable una determinada norma cuando "no se ha determinado el derecho aplicable al caso", precisamente "porque en muchos casos las sentencias de los tribunales, exceptuando la Corte Suprema, pueden ser enmendadas por sus superiores jerárquicos"13. Lo que hace el Tribunal Constitucional entonces, es ser una mera guía ex ante para que el tribunal a quo falle, pero en ningún caso significa que la inconstitucionalidad no se pueda cometer. Gastón Gómez ha dicho que: "El valor de las sentencias y de sus razones o criterios de interpretación dependen, en buena medida, de cómo los tribunales [ordinarios] los apliquen"14. La situación denunciada es consecuencia de un diseño, como dice "prospectivo", ex ante, respecto de la posible y eventual aplicación de una ley a unos hechos de un caso en progreso. Así, la declaratoria de inaplicabilidad, en lugar de ser un freno a toda inconstitucionalidad que pueda contaminar el caso, se convierte simplemente en la remoción de un escollo eventual para un caso también eventual.

Haciendo suyas las palabras de Eduardo Aldunate, Luis Alejandro Silva ha dicho que, "para decidir una inaplicabilidad, el Tribunal Constitucional tiene la dificil tarea de proyectar la posible aplicación de un precepto legal, para entrar luego a evaluar la constitucionalidad de la misma"; citando a Verdugo, señala que este

\footnotetext{
12 Vega y ZúNítga (2006), p. 155, dijeron en su momento: "el Tribunal Constitucional se erige en un tribunal de super casación; y funcionalmente hablando, supraordenado al Poder Judicial y a la Justicia Electoral, en el sentido que, en lo que respecta al control de constitucionalidad de una norma legal, la única y última palabra la tiene el Tribunal Constitucional".

13 Silva (2012a), pp. 589 y 590.

14 Gómez (2013), p. 246
} 
examen de constitucionalidad es meramente "prospectivo"15. A su turno, Núñez citando también a Eduardo Aldunate, ha dicho que el recurso de inaplicabilidad es de carácter "adivinatorio". Este autor ha dicho que la jurisprudencia del Tribunal Constitucional exige la "sola posibilidad" o bien una "posibilidad real" de que el precepto impugnado sea aplicado al caso, no siendo suficiente una mera posibilidad "hipotética y teórica", que convertiría al recurso de inaplicabilidad en un control abstracto ${ }^{16}$. Esta crítica ha llevado a Eduardo Aldunate, con razón, a proponer el control no sólo de la ley, sino de la sentencia judicial que lo aplica ${ }^{17}$.

Se ha dicho que el art. 93 número 6 de la Constitución en parte alguna le da el carácter de "prospectivo" a este examen de constitucionalidad. Pero la jurisprudencia del Tribunal Constitucional lo ha entendido como un examen respecto de una posible o eventual aplicación de una ley, y no como la efectiva y presente aplicación de una ley. ¿Es esto correcto? A mi juicio, sí; y es perfectamente fiel con el (defectuoso) diseño institucional. Esto, porque no existe otra manera de interpretar el art. 93 número 6 que no sea como un examen eventual, "imaginando el sentido en que (la norma) puede resultar inconstitucional"18, si entendemos que el Tribunal Constitucional siempre deberá pronunciarse sobre la aplicación de la ley en los casos en que "existan gestiones pendientes" en el juicio en concreto. De lo contrario, se diría que el Tribunal Constitucional tiene la última palabra en el juicio, y se pronunciaría al final del caso acerca de la efectiva aplicación de la ley, lo que no ocurre.

Manuel Núñez habla de la "dispensa de Tribunal a tribunal, que aunque no libera al juez de la gestión de su inexcusable deber de fallar, lo exime de la obligación de aplicar el precepto legal cuestionado si se han dado todos los supuestos hipotéticos para

15 Silva (2012), p. 591, citando a Aldunate (2010) p. 3.

16 NúNez (2012), p. 42, citando a Aldunate (2007), pp. 53-44, a propósito de la STC Rol No 1445 de 21 de enero de 2010 caso Sánchez Eyquem. En el mismo sentido se pronuncia Gómez (2013) acerca de la sentencia STC 707 (2005) Forestal Mininco, que en los considerandos 13 y 14 resolvió: "que aunque en abstracto (...) los artículos 15 y 16 del decreto ley $N^{o} 2.695$ (...) aparece como un modo especial de adquirir el dominio legalmente establecido y que tiene una causa justificada que hace razonable su especialidad frente a las normas generales sobre posesión y dominio de los bienes raices del Código Civil, sin que pueda estimarse que entrañe una privación inconstitucional de la propiedad, en su aplicación concreta al caso de que conoce actualmente (...), sin que a juicio de este Tribunal, concurran en la especie los motivos que justifican la aplicación de aquellas normas especiales, las cuales, en el caso de ser utilizadas, constituirían una diferencia arbitraria y podrian dar origen a una privación inconstitucional de la propiedad" (destacado es nuestro).

17 Aldunate (2007), p. 35.

18 SiLVA (2012a), p. 591. 
que la norma sea aplicable al caso. Esta dispensa particular genera un pseudo-vacio legal o una laguna impropia, que es inmediatamente llenada por las reglas comunes y los principios generales que corresponden en virtud del principio de inexcusabilidad"19. Lo que Núñez y otros teóricos no dicen es que esta "laguna impropia" a veces es llenada por el tribunal ordinario -la Corte Suprema en muchos casos- con la aplicación de normas que redundan en una solución igual de injusta que la que la inaplicabilidad quería evitar ${ }^{20}$.Como ha dicho Silva, el diseño de la inaplicabilidad es un "imposible", al existir este "desajuste entre la descripción del supuesto de hecho de la inaplicabilidad-que exige la aplicación de un precepto legal-y la posibilidad del juicio de inaplicabilidad-que inevitablemente recaerá sobre la eventual aplicación de un precepto legal"21.

El problema no consiste, como se ha dicho, en una superposición de competencias, en que la Corte Suprema se inmiscuya en la esfera del Tribunal Constitucional (o viceversa, en otros casos). El problema, como he señalado, radica en el momento en que ello ocurre. Siendo un requisito de admisibilidad de la acción de inaplicabilidad la existencia de "gestiones pendientes", lo cierto es que siempre existirá - debe existir- un pronunciamiento ulterior del juez ordinario, que podrá dejar sin efecto lo resuelto por el Tribunal Constitucional, entre otras razones, porque sus sentencias parecen no ser realmente vinculantes. Por tanto, el problema acerca de quién interpreta la ley aparece como artificial: lo importante es cuándo lo hace.

\section{LA INAPLICABILIDAD POR INCONSTITUCIONALIDAD}

\section{NO ES UN RECURSO}

Quiero reparar un momento en la nomenclatura dada por buena parte de la doctrina a esta acción constitucional. Al igual que con la acción de protección, nuevamente se emplea la voz "recurso", que se presta para equívocos, y que aparece como una de las fuentes de confusión y frustración entre los operadores jurídicos. El recurso de inaplicabilidad no es un recurso procesal. El problema es que la doctrina ha elaborado sus teorías sobre la base de la idea de que se trata efectivamente de un recurso, y ha tratado de exigir de él el rendimiento que se espera de un medio de impugnación procesal. Dice Ludwig Wittgenstein que "el

19 NúNEZ (2012), p. 43.

20 NúNÉEZ (2012), p. 44.

21 SiLVA (2012a), p. 591. 
significado de una palabra es su uso en el lenguaje"22. En el lenguaje de la doctrina constitucional se dice que es un recurso, pero el uso que se hace de la palabra (del concepto) corresponde a una idea diferente. Mosquera y Maturana reconocen que "no nos encontramos en presencia de un recurso propiamente tal" 23 . Se ha insinuado por parte de la doctrina que la inaplicabilidad sería en realidad un "incidente" al juicio principal, lo que tampoco parece correcto, ya que los incidentes debieran zanjar ciertos asuntos de forma inamovible dentro del proceso, lo que no ocurre necesariamente con este recurso. En este sentido, es decidor que ni la Constitución ni la Ley Orgánica Constitucional del Tribunal Constitucional empleen la voz "recurso" 24 .

\section{LA APLICACIÓN DE LA LEY Y EL CONTROL DE CONSTITUCIONALIDAD FINALISTA RESPECTO DE LA NORMA A APLICARSE}

Lo que el Tribunal Constitucional hace es controlar la constitucionalidad de la aplicación de una norma legal a un caso concreto. Por lo tanto, existen al menos dos operaciones diferentes:

(i) dilucidar qué es aplicar la ley a los hechos de un caso concreto, y

(ii) saber en qué consiste controlar la constitucionalidad de esa aplicación de la ley a los hechos del caso.

¿En qué consiste aplicar una norma a los hechos del caso? La aplicación de una norma al caso concreto aparece como una relación lógica deductiva, en que existe una premisa que tiene la forma de una proposición condicional, con un antecedente y un consecuente. La segunda premisa es la afirmación del antecedente condicional, y finalmente existe una conclusión que es una afirmación del consecuente. Siguiendo el ejemplo que da Manuel Atienza: (i) Premisa condicional:

22 Wittgenstein (2012), p. 61.

23 Mosquera y Maturana (2010), p. 506. Los autores dan las siguientes razones: (i) "no se impugna resolución judicial alguna"; (ii) "no se pretende la modificación, enmienda o invalidación de resolución judicial alguna dictada dentro de un proceso" (iii) "no existe un gravamen" y "el recurso puede deducirse aun antes de haberse dictado resolución alguna dando aplicación al precepto legal inconstitucional. Todavía más, podría darse el caso hipotético que - desestimada la inaplicabilidad-nunca llegara a existir gravamen, si el Tribunal llegara a interpretar la ley en forma diferente a lo que en ese momento estimó el litigante".

24 PAREDES (2012), p. 294 dice que: "la Constitución no utiliza ninguna denominación para hacer referencia a la atribución del artículo 93 No 6. La nueva LOTC habla de 'cuestiones de inaplicabilidad' (...). No obstante, la mayoría de los autores hablan de 'acción de inaplicabilidad, denominación que ha logrado imponerse en la práctica. A su vez, el sitio web del Tribunal Constitucional utiliza la expresión 'requerimiento de inaplicabilidad'”. 
"el juez que cometa un acto de prevaricación debe ser condenado a la pena de un año". Este lenguaje legal puede ser traducido al lenguaje condicional del que habla Atienza en los siguientes términos: "si se acredita que un juez cometió un acto de prevaricación, debe ser condenado a la pena de un año"25. (ii) Antecedente condicional: que exista un juez que haya cometido un acto de prevaricación. (iii) Consecuente: si existe el antecedente condicional, debe aplicarse la pena.

Esta lógica deóntica o lógica de las normas plantea el problema de si es posible afirmar como "verdadera" o "correcta" las conclusiones que se obtienen a partir de este tipo de operaciones deductivas, o de las inducciones que se hacen a través de los medios de prueba en el proceso ${ }^{26}$. Es un problema que echa sus raíces en la filosofía del lenguaje, como lo expusiera, por ejemplo, John Searle en su enunciado acerca de la "derivación del "debe" a partir del "es" 27. Esta operación de deducción o de subsunción lógica la efectúa el tribunal ordinario, dentro de las competencias que orgánicamente le están dadas. El juez efectúa la operación lógica de contrastar el presupuesto condicional del enunciado normativo con los supuestos de hecho que se han sometido a su conocimiento. Si los hechos concretos son subsumibles, aplicará la ley y extraerá una determinada conclusión también contenida en la ley. Este esquema corresponde evidentemente a una simplificación: por así decirlo, corresponde a la aplicación de la ley a los "casos fáciles"; la filosofía del Derecho se ha interesado en elaborar varias teorías para explicar la solución de los casos "difíciles" o de "textura abierta" (aquellos en que parece no existir norma que resuelva el caso), entre las cuales destaca la muy conocida polémica entre Herbert Hart y su "Concepto del Derecho" y las críticas posteriores de Dworkin, y las complementaciones de $\mathrm{MacCormick}^{28}$, o las teorías procesales recogidas por Manuel Serra ${ }^{29}$ respecto del juicio jurisdiccional, como aplicación de un juicio valorativo, no ya lógico ni de mera aplicación de la ley.

25 ATIENZa (2013), p. 171.

26 ATIENZa (2013), pp. 175-176: "es un problema complejo y no resuelto aún de manera satisfactoria (...) los resultados que ha arrojado hasta ahora la lógica deóntica, en relación con el estudio de los razonamientos jurídicos, son bastante modestos, entre otras cosas porque esa lógica (o esas lógicas: hay muchisimos sistemas de lógica deóntica) se ha limitado, por regla general, a un único tipo de enunciado normativo (las reglas de acción) y ha dejado fuera los principios, las reglas constitutivas, los enunciados de valor, etcétera".

27 Cfr. Searle (2009), pp. 178 y siguientes. También el interesante trabajo de Von Wright (1997).

28 Cfr. Hart (1998); Dworkin (2012a y b); y MacCormick (2010).

29 Serra (2008), pp. 78-105. 
Aclarado entonces (o al menos intentado aclarar) en qué consiste la aplicación de la ley al caso concreto, corresponde revisar en qué consiste el control de constitucionalidad propiamente tal respecto de la norma ya aplicada al caso ${ }^{30}$. Como dice Núñez, lo que hace el Tribunal Constitucional es analizar si en un caso determinado, la aplicación de una norma legal a los hechos pudiera generar efectos opuestos a la finalidad implícita de la Constitución ${ }^{31}$. Es, entonces un examen finalista; y no podría ser de otro modo, si se trata de una consecuencia eventual que la norma generará de aplicarse a los hechos del caso. El Tribunal Constitucional no hace una subsunción o una deducción lógica en que concluya que algo debe o no debe hacerse por ser correcto o incorrecto. Lo que hace es ponderar la eventual aplicación de la norma legal con los fines pretendidos por la Constitución: si los principios constitucionalmente garantizados se ven frustrados en el caso concreto, la norma deberá ser inaplicada ${ }^{32}$.

La inaplicabilidad por inconstitucionalidad pretende acotar el catálogo de leyes a las que puede recurrir el tribunal del fondo al resolver el caso, y quizás es esta la principal falencia de nuestro modelo. Por lo general, los sistemas de Derecho no obligan al juez del fondo a aplicar una norma u otra. El juez es por completo

30 PICA (2010), p. 365: "en un texto profusamente citado por la jurisprudencia del Tribunal Constitucional, el profesor Lautaro Ríos sostiene, centrado, al igual que Núnez, en la doble relación del caso, que la inaplicabilidad cumple la función de impedir que la parte que la invoca en el caso concreto del que conoce un tribunal, se vea afectada por un precepto legal cuya aplicación a ese caso particular resulte evidentemente contraria a la Constitución y, especialmente, a los fines perseguidos por ésta'...".

31 NÚÑEZ (2008), p. 127: "comparecen tres elementos de cotejo necesarios para su decisión; a saber: la norma constitucional, el precepto legal cuya inaplicación se solicita y-lo más especificamente decisivo-el examen particular acerca de si "en ese caso la aplicación del precepto cuestionado pudiera generar efectos opuestos a la finalidad implícita de aquella"... Por eso, puede advertirse que hay preceptos legales que pueden estar en perfecta consonancia con la carta fundamental y, no obstante ello, ser inaplicables a un caso particular, precisamente porque en la particularidad de ese caso, la aplicación de una norma legal objetada es contraria a los efectos previstos por la norma constitucional". KeLSEN (2009), p. 314, decía que era necesario confrontar dos elementos, el "hecho concreto" con la Constitución: "el "hecho concreto", que en la decisión acerca de la constitucionalidad de una ley es subsumido bajo la norma constitucional, no es una norma - hecho concreto y norma son dos nociones diferentes-, sino que es la producción de una norma".

32 Atienza (2013), p. 184: "el esquema finalista es más abierto, deja más discrecionalidad al juez: como las reglas de acción se orientan al pasado, en la premisa fáctica del razonamiento subsuntivo o clasificatorio se trata de establecer simplemente que ha tenido lugar un hecho; pero las reglas de fin miran al futuro, de manera que en el correspondiente esquema argumentativo hay una premisa que enuncia un juicio predictivo sobre lo que ocurrirá o no ocurrirá en el futuro; y el futuro es más abierto y (en general) más complejo que el pasado. Por eso, el esquema finalista juega un papel más bien excepcional en el razonamiento judicial, mientras que es central en el razonamiento que efectúan los legisladores, los órganos de administración o los abogados, cuando aconsejan un curso de acción a sus clientes". 
soberano para aplicar una norma u otra, con la única limitante del principio de inexcusabilidad: o sea, debe resolver el caso. El principio del iura novit curia ("el tribunal conoce el Derecho") tiene una larga tradición en nuestro Derecho, y ha sido reconocido por reciente jurisprudencia ${ }^{33}$. El juez no está ligado por las pretensiones jurídicas de las partes, sino sólo por los hechos acreditados en el proceso. Entonces, lo que el Tribunal Constitucional hace es simplemente restringir un catálogo absolutamente abierto e indeterminado de normas a las que puede acudir el juez, lo que es lo mismo que decir que no restringe nada. Este problema ha sido entendido deficientemente como que el Tribunal Constitucional carecería de facultad de imperio y que "está provisto, ex profeso, de auctoritas y no de potestas" 34 . Otros, ven en esta supuesta "desobediencia" de los tribunales ordinarios una manifestación de "activismo judicial" 35 , o incluso una actitud de "indiferencia" de la Corte Suprema respecto de lo que el Tribunal Constitucional resuelve ${ }^{36}$. Creo que el problema no es ese, sino que (y aunque tuviera imperio)

33 En este sentido, Romero (2014), p. 27.

34 Gómez (2013), p. 62.

35 García y Verdugo (2013), p. 139, analizando algunos casos en que las Cortes de Apelaciones y la Corte Suprema "desobedecieron" al Tribunal Constitucional, han dicho que: "los razonamientos judiciales analizados fueron problemáticos, por cuanto cuestionan la autoridad del Tribunal Constitucional. El problema institucional se traduce en que este Tribunal carece de mecanismos para hacer obligatorias sus sentencias para los jueces ordinarios, lo que ha mermado su autoridad. Es la Corte Suprema, finalmente la encargada de velar porque las normas se apliquen. Cuando esta Corte no da señales claras de estar obedeciendo al Tribunal Constitucional, y compite con él, se abre un terreno fecundo para que tribunales inferiores a ella (como Cortes de Apelaciones) también desobedezcan al Tribunal Constitucional". Como se sostiene en el presente trabajo, no es que exista realmente una obligación por parte de los tribunales ordinarios de "obedecer" al Tribunal Constitucional, sino sólo de no aplicar la norma declarada inconstitucional en sus sentencias. Y eso es lo que han hecho las Cortes. Por lo mismo, las acusaciones de activismo judicial, o de "pugna" entre Cortes me parecen equivocadas: los tribunales ordinarios no necesitan recurrir al "activismo" ni menos desobedecer a quien no deben obligación de obediencia. Estos autores llegan a conclusiones apresuradas sobre la base de premisas que no son exactas. Dicen, p. 132 que, "nuestra cultura juridica suele concordar en que el Tribunal Constitucional tiene el monopolio del control de constitucionalidad de la ley, y que las Cortes tienen la obligación de seguir las sentencias de inaplicabilidad", lo que es correcto. Pero de ello no se puede concluir que los tribunales ordinarios tengan una obligación de fallar como "parece indicar el Tribunal Constitucional que el caso debe fallarse". Ojalá existiera claridad en nuestro sistema al respecto, pero mientras no la haya, los fallos del Tribunal Constitucional no imponen directriz alguna respecto a cómo debe fallarse el fondo, más allá de inaplicar una determinada norma.

36 Cfr. Viera (2012) y García Barzelatto (2013). Estos autores analizan el fallo del caso "Gómez Montoya" (2012), en que la Corte Suprema rechazó un recurso de protección que previamente había sido acogido por la Corte de Apelaciones de Valparaíso, en un caso en que el recurrente era un ministro de esa Corte, a quien la Corporación Administrativa del Poder Judicial (CAPJ) negó el pago de un bono, aduciendo que el recurrente había trabajado menos de seis meses en ese año, en razón de una enfermedad catastrófica. La ley aplicable hacía obligatorio en pago de los bonos, aun cuando el funcionario hubiera trabajado menos de 
sus fallos no imponen ninguna vía obligatoria al juez del fondo. El juez del fondo cumple su cometido sólo si se abstiene de aplicar la norma proscrita por el Tribunal Constitucional, pero puede aplicar cualquier otra. En el prólogo de la obra de Gastón Gómez, Carlos Peña precisamente alude a Wittgenstein, en lo referido a que "ningún curso de acción puede ser determinado por una regla, porque cualquier curso de acción puede hacerse concordar con la regla" 37 . En este caso, el juez ordinario puede hacer coincidir su curso de acción con la regla establecida por el Tribunal Constitucional. Es interesante advertir que en el modelo chileno, a diferencia del sistema español o italiano, el juez a quo no hace ningún juicio de relevancia ex ante de la norma a inaplicar al caso concreto, por lo que todo el proceso de inaplicabilidad se desarrolla (en la mayoría de los casos) sin su intervención. Esto podría explicar la indiferencia del Poder Judicial respecto de las sentencias de inaplicabilidad ${ }^{38}$.

Por estas razones, me parece inoficiosa la polémica acerca de si el Tribunal Constitucional y la Corte Suprema se inmiscuyen mutuamente en la aplicación de la ley y en la decisión de la constitucionalidad de la aplicación de esa ley ${ }^{39}$.

seis meses en el año, sólo si la enfermedad era de carácter laboral, lo que no ocurrió en este caso. El Tribunal Constitucional declaró inaplicable esa norma, en razón de su evidente arbitrariedad, pero la Corte Suprema finalmente rechazó el recurso, aduciendo que cuando la CAPJ había aplicado la ley, ésta no había sido declarada inaplicable, y que los fallos del Tribunal Constitucional no tenían efecto retroactivo. El fallo, de redacción del ministro Pedro Pierry, fue profusamente criticado; así en García y Verdugo (2013), pp. 134136. Aunque excede con mucho el objeto de este trabajo, este fallo tan criticado tiene cierta lógica, de acuerdo al defectuoso diseño institucional que he denunciado: la Corte Suprema parece haber estimado que lo que realmente se juzgaba no era la aplicación de la norma en el recurso de protección, sino su aplicación anterior por parte de la CAPJ, o sea, la legalidad de una resolución administrativa.

37 Gómez (2013), p. 5, en referencia a Wittgenstein (2012), p. 203: "201. Nuestra paradoja era ésta: una regla no podía determinar ningún curso de acción porque todo curso de acción puede hacerse concordar con la regla. La respuesta era: Si todo puede hacerse concordar con la regla, entonces también puede hacerse discordar. De donde no habría ni concordancia ni desacuerdo".

38 En este sentido, PAREDES (2012), p. 298.

39 Aplicar la ley a los hechos del caso y decidir acerca de la constitucionalidad de esa aplicación son, por lo tanto, operaciones estrechamente vinculadas. Este estrecho vínculo es el que posiblemente explica muchas de las confusiones que se generan en la doctrina respecto de la supuesta pugna entre la Corte Suprema y el Tribunal Constitucional. SiLva (2012a), p. 604, dice que: "Jorge Correa admite la dificultad de precisar si el efecto contrario a la Constitución lo produce una determinada interpretación legal o una decisión judicial que lo aplica. Y la razón de esta dificultad "se deriva de que precisamente las normas sólo pueden producir un efecto en los casos a través de los jueces. El efecto contrario a la Carta en un caso no lo puede producir la norma sino a través del juez que la aplica". Pero luego el mismo Correa reprocha que se infiera de esto que la inaplicabilidad es un medio de impugnación de resoluciones judiciales. Ofrece como explicación lo siguiente: "decenas de requerimientos de inaplicabilidad han sido rechazados o declarados inadmisibles precisamente por impugnar la constitucionalidad 
Que la vulneración a la Constitución tenga lugar en la aplicación o interpretación prospectiva de la norma a los hechos, o si ello ocurre en la sentencia misma, da igual en un sistema en que la última sentencia la declarará el tribunal ordinario, y no el Tribunal Constitucional. El Tribunal Constitucional no controla la constitucionalidad de las sentencias. Ciertamente su labor es inseparable de la aplicación de la ley al caso, pero a partir de la reforma de 2005 la atención hay que ponerla no en lo que el Tribunal Constitucional hace, sino en qué momento despliega su poder. El Tribunal Constitucional entiende que su labor no es impugnar resoluciones judiciales. El Tribunal Constitucional está en perfecta conciencia que no tiene la última palabra en el caso.

\section{LA PROCEDENCIA DEL RECURSO DE PROTECCIÓN EN CONTRA DE SENTENCIAS JUDICIALES}

He sostenido en este trabajo que (i) la inaplicabilidad por inconstitucionalidad no es realmente un recurso procesal; (ii) que sólo produce un efecto ex ante respecto de futuras y eventuales decisiones judiciales que se pronuncien en el proceso; (iii) que aun acogiéndose la inaplicabilidad, el tribunal ordinario goza de plena libertad para arribar a una solución igual de arbitraria que la que se pretendía evitar; (iv) que sus sentencias no son obligatorias precisamente porque no tienen por objeto anular las decisiones de los tribunales ordinarios, y que en fin, (v) en los casi diez años de funcionamiento, sus resultados como "guardián de la Constitución" (al menos en lo referido al ius litigatoris) han sido más que modestos.

La pregunta que hay que hacerse es si existe algún remedio para esta situación. Es decir, si existe alguna forma de controlar ex post la constitucionalidad de las decisiones judiciales. La respuesta a esta pregunta es la siguiente: efectivamente existe en nuestro ordenamiento una poderosa herramienta que permite resguardar los derechos fundamentalmente garantizados de sus ciudadanos, y esa herramienta es el recurso de protección. Esta idea, sin duda polémica y controvertida (y sobre todo, resistida por el Poder Judicial) no es original ni nueva, y tuvo cierto auge

de lo resuelto por los jueces de instancia y no preceptos legales". Esta explicación no es satisfactoria, porque el número de sentencias por si solo no explica nada. No niego la existencia de esas sentencias, pero niego que ellas demuestren lo que Correa pretende. Si realmente el enjuiciamiento constitucional del precepto legal no puede separarse de su aplicación judicial, como antes afirmó, ¿cómo puede ser que la impugnación de un precepto se separe de la impugnación de la resolución que lo aplica?". 
en los comienzos de la década de 1990. Sin embargo, su implementación resulta hoy imperiosa para llenar el sensible vacío que la reforma de 2005 dejó respecto del control último de sentencias civiles que vulneren gravemente las garantías fundamentales.

Lo primero que hay que decir es que no existe argumento de texto, como tampoco en la historia de la Constitución de 1980, que permita sustentar a priori que el recurso de protección no es una vía idónea para impugnar una sentencia judicial. En este sentido, no es posible privar al recurso de protección de su dimensión plenamente recursiva e impugnatoria de sentencias judiciales. Es decir, como un recurso procesal más. Sin embargo, es imprescindible reconocer que la doctrina mayoritaria, lo mismo que la jurisprudencia, niegan la procedencia del recurso de protección respecto de fallos civiles o arbitrales" 40 . Sin perjuicio de esas opiniones que debo reconocer mayoritarias, en general, el recurso de protección es concebido en nuestro ordenamiento como una "acción cautelar" para asegurar la protección del afectado" ${ }^{41}$. Como cautelar de carácter general, Waldo Ortúzar ha sostenido en un interesante trabajo del año 1994 que: "El recurso de protección contra resoluciones judiciales es procedente de conformidad con lo que dispone el artículo 20 de la Constitución Politica de la República, cuyo sentido es claro, pues no distingue acerca de las personas u órganos que ejecuten los actos u omisiones arbitrarias o ilega-

40 Por todos, Mosquera y Maturana (2010), p. 417; Romero (2004), p. 61, aunque este último tiene una visión ligeramente crítica de la situación actual; PICA (2010), p. 354. Este autor tiene una visión expansiva $\mathrm{u}$ optimista acerca del alcance de la inaplicabilidad, que en la jurisprudencia del Tribunal Constitucional cuesta encontrar. Dice este autor, p. 356, que: "estas ideas llevan necesariamente a constatar que en el sistema chileno ya "no sólo el producto de la actividad del legislador estará sujeto a control de constitucionalidad, sino que también las resoluciones de los jueces y magistrados", en la medida que la única forma posible de aplicación de un precepto legal a un caso concreto de resolver ante un tribunal ordinario o especial es la dictación de resoluciones judiciales a su amparo, interpretando el precepto y subsumiendo en él los hechos litigiosos, para, mediante dichas resoluciones judiciales, producir un determinado resultado que se traduce en resolver la gestión de determinada forma, lo que, si produce un resultado contrario a la Constitución será declarado inconstitucional de manera preventiva, antes de que ello ocurra, en sede de inaplicabilidad, o bien, si ya se produjo, en ciertos casos la sentencia de inaplicabilidad operará como "amparo imperfecto o cuasiamparo". Como se ha sostenido en esta investigación, la inaplicabilidad a cargo del Tribunal Constitucional parece estar muy lejos de ser un efectivo amparo constitucional, reduciéndose a un mero control ex ante sobre la eventual aplicación de leyes a un caso concreto.

41 Mosquera y Maturana (2010), p. 408. En el mismo sentido, Marín (2014), pp. 95 y ss. En contra, ROMERo (2014), p. 170, quien no comparte esta supuesta naturaleza cautelar, "puesto que la pretensión de todo recurrente al intentar esta vía es obtener alguna de las tres formas clásicas de protección jurídica, esto es, la condena, la declaración o la constitución de un nuevo estado jurídico". 
les 42 ", aludiendo a un argumento histórico: "Cuando se discutió en la Comisión de Estudio de la Nueva Constitución la naturaleza y efectos del Recurso de Protección, se admitió la idea de hacerlo procedente aún en caso de ser interpuesto para obtener la reparación de un menoscabo, agravio o daño causado a alguna persona, inferido por alguna resolución judicial"'43. En el mismo sentido, Eduardo Soto-Kloss ha dicho que el recurso de protección "tiene lugar en los casos en que sea este remedio constitucional una solución rápida y eficaz allí donde la vía ordinaria conduzca a una denegación o dilación de justicia o a algún agravio irreparable". ${ }^{44} \mathrm{El}$ artículo 20 de la Constitución en su inciso primero dispone que la Corte, "adoptará de inmediato las providencias que juzgue necesarias para restablecer el imperio del derecho y asegurar la debida protección del afectado". Al respecto se interroga Ortúzar: "¿Se compadece esa urgencia en el caso de agravio constitucional con la negativa a conocer de la acción de protección porque el autor del agravio es un juez y lo cometió en una resolución judicial? ¿Se puede afirmar a priori que el agraviado, que dice amagada una garantía constitucional y el acto mismo denunciado se encuentran bajo el imperio del derecho, por la circunstancia que dicho acto tuvo lugar en un proceso judicial? Debe responderse negativamente puesto que los recursos jurisdiccionales y disciplinarios no tienen la rapidez y la urgencia que la Constitución exige para sustanciar los efectos propios de la acción de protección".

A propósito de las sentencias civiles emanadas de tribunales arbitrales, Patricio Aylwin en su célebre obra sobre este tema ha dicho, citando una jurisprudencia, que: "el hecho de que las partes sometan un determinado asunto o contrato a la interpretación, conocimiento y resolución de un tribunal arbitral "no obsta a la competencia que la Constitución ha conferido a las Cortes de Apelaciones para conocer del recurso de protección, que tiene por objeto conocer de manera urgente y excepcional de las violaciones a derechos fundamentales, amagados por una acción u omisión arbitraria o ilegal" 45 . Cita este autor una jurisprudencia del año 1990 que acogió un recurso de protección respecto de una medida precautoria decretada por un

42 Ortúzar (1994), p. 8.

43 Ortúzar (1994), p. 6, citando las Actas Oficiales de la Comisión Constituyente, sesión 214, de 25 de mayo de 1976, la intervención del Presidente de la Comisión Constitucional, don Enrique Ortúzar Escobar: "Del mismo modo, un juez que sin que se haya incoado un proceso, donde naturalmente pueden tener lugar los recursos que la ley establece, lisa y llanamente atente contra el derecho de propiedad dictando una resolución abusiva, violando el domicilio de un ciudadano cualquiera. ¿Por qué no va a poder ejercerse este recurso?”.

44 Soto-Kloss (1982), pp. 252-253.

45 AYLWIN (2009), p. 464. 
árbitro que gravaba los bienes de los socios, que no eran parte de un arbitraje entre sociedades, por estimarse violentada la igualdad ante la ley de un tercero que no pudo defenderse en juicio como sí pudieron hacerlo las partes ${ }^{46}$. Emilio Pfeffer, aunque no reconoce explícitamente la procedencia de la protección respecto de vulneraciones ocurridas en la sentencia misma, ha dicho que, "debe ser corregida directamente por los tribunales del fondo y no por la vía de la declaración de inaplicabilidad del precepto legal 47 ". Este autor ha sido enfático en afirmar que "en Chile la acción de inaplicabilidad no fue concebida para dar origen a un proceso

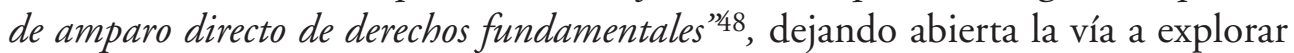
otras opciones como la que se propone en este trabajo. Por lo demás, la idea de que exista un control constitucional de las sentencias civiles no es controvertida en el derecho comparado, como sucede en Alemania ${ }^{49}$, España ${ }^{50}$, o Colombia ${ }^{51}$

46 AYLWIN (2009), pp. 464-465, citando un fallo de la Corte de Apelaciones de Santiago: "la resolución de un juez árbitro arbitrador que decreta medidas precautorias sobre bienes personales de los socios de una sociedad bajo su jurisdicción arbitral excede manifiestamente el ámbito de su competencia, afectando de modo ilegal y arbitrario el derecho de propiedad de dichos socios, reconocidos por la Constitución, desde que éstos son jurídicamente ajenos al arbitraje. Atenta contra el derecho a la igualdad (art. $19 N^{o} 2$ de la Constitución) la resolución de un juez árbitro que afecta a terceros ajenos a su jurisdicción arbitral, puesto que éstos quedan en situación desmedrada para actuar procesalmente y defender con expedición y en términos igualitarios sus derechos dentro del propio juicio de compromiso, dado que son extraños a ese procedimiento".

47 Pfeffer (2011), p. 210.

48 Pfeffer (2011), p. 206.

49 La Constitución de la República Federal Alemana en su parágrafo 90, apartado 1 dispone que: "cualquiera que afirme encontrarse lesionado por el poder público en alguno de sus derechos fundamentales o en alguno de los derechos contemplados en el artículo 20, apartado 4, y artículos 33, 38, 101, 103 y 104 de la Ley Fundamental, puede interponer el recurso de amparo constitucional ante el Tribunal Constitucional Federal". Acerca del amparo en el derecho alemán, ver el trabajo de VON MüNCH (1979).

50 Cfr. Fernández (2005), p. 3. El artículo 44 de la Ley Orgánica del Tribunal Constitucional español dispone lo siguiente: "Las violaciones de los derechos y libertades susceptibles de amparo constitucional, que tuvieran su origen inmediato y directo en un acto u omisión de un órgano judicial, podrán dar lugar a este recurso siempre que se cumplan los requisitos siguientes: a) Que se hayan agotado todos los medios de impugnación previstos por las normas procesales para el caso concreto dentro de la vía judicial. b) Que la violación del derecho o libertad sea imputable de modo inmediato y directo a una acción u omisión del órgano judicial con independencia de los hechos que dieron lugar al proceso en que aquellas se produjeron, acerca de los que, en ningún caso, entrará a conocer el Tribunal Constitucional. c) Que se haya denunciado formalmente en el proceso, si hubo oportunidad, la vulneración del derecho constitucional tan pronto como, una vez conocida, hubiera lugar para ello. El plazo para interponer el recurso de amparo será de 30 días, a partir de la notificación de la resolución recaida en el proceso judicial".

51 El artículo 86 de la Constitución de Colombia dispone que: "toda persona tendrá acción de tutela para reclamar ante los jueces, en todo momento y lugar, mediante un procedimiento preferente y sumario, por símisma o por quien actúa a su nombre, la protección inmediata de sus derechos constitucionales fundamentales, cuando quiera 
y Perú 52 para dar ejemplos más cercanos. La situación del derecho chileno es hoy ciertamente minoritaria, y hasta cierto punto paradójica.

\section{LAS OBJECIONES DOCTRINARIAS Y JURISPRUDENCIALES RESPECTO}

DE LA PROCEDENCIA DEL RECURSO DE PROTECCIÓN EN CONTRA

\section{DE SENTENCIAS JUDICIALES}

Existen varios "tabús" difíciles de derribar para admitir la procedencia del recurso de protección respecto de sentencias judiciales, y que explica la escasa acogida que ha tenido esta acción de protección en los últimos veinte años por parte de la Corte Suprema, cuando se ha intentado impugnar una decisión judicial. Esta intuición contraria a admitir el recurso de protección como un verdadero recurso procesal se apoya en algunos argumentos, que paso a exponer y refutar.

\section{La objeción orgánica o politica, y la falta de legitimidad democrática del Poder Judicial}

Se trata del desplazamiento del rol de "guardián de la Constitución" desde el Tribunal Constitucional -que no depende del Poder Judicial-a los tribunales ordinarios, en particular, a la Corte Suprema, que revisa por la vía de apelación las sentencias de protección. ¿Es éste un problema real? En realidad, sucede que son los tribunales ordinarios -varios de ellos inferiores- los que controlan la constitucionalidad de gran cantidad de actos y sentencias. El Tribunal Constitucional está circunscrito a revisar la constitucionalidad de ciertas normas, en un control supuestamente concreto, pero que hemos visto no surte efectos

que éstos resulten vulnerados o amenazados por la acción u omisión de cualquier autoridad pública", incluyéndose dentro de estas últimas las resoluciones judiciales. Respecto del amplísimo rango de acción de la tutela en el derecho de Colombia, ver el trabajo de CARRERA (2011). Un análisis muy acabado de la jurisprudencia de la Corte Constitucional colombiana se encuentra en el conocido trabajo de López Medina (2008).

52 El artículo 200 de la Constitución de Perú dispone que: "son garantías constitucionales: (...) 2. La Acción de Amparo, que procede contra el hecho u omisión, por parte de cualquier autoridad, funcionario o persona, que vulnera o amenaza los demás derechos reconocidos por la Constitución, con excepción de los señalados en el inciso siguiente. No procede contra normas legales ni contra resoluciones judiciales emanadas de procedimiento regular". Al respecto, ha dicho Trujillo (2003), pp. 271-272 que, "es la propia Constitución la que nos pone el primer límite al cuestionamiento de una resolución judicial, y con ello un requisito especial de procedencia de una Acción de Amparo contra una resolución judicial. Así pues tenemos que para poder hacer uso de este instrumento de protección constitucional contra una Resolución Judicial debemos encontrarnos frente a un proceso irregular". En el mismo sentido, el art. $6^{\circ}$ de la ley No 23.506 dispone que no proceden las acciones de garantía "contra resolución judicial emanada de un procedimiento regular". 
en el proceso en buena parte de los casos. Por tanto, no puede hablarse de un real desplazamiento. El "nuevo" Tribunal Constitucional "nació" desplazado, fruto de un diseño institucional inadecuado. Quien tiene el verdadero poder de controlar la Constitución parece ser (y siempre ha sido) el Poder Judicial. Como acota Rodrigo Pica: "nuestro sistema tiene un Tribunal Constitucional sin potestades de amparo, que queda entregado sólo a los tribunales ordinarios" 53 , y "hoy los Tribunales Constitucionales no son principalmente garantes de la Constitución contra el legislador, sino más bien se erigen como intérpretes de la Constitución" 54. Desde 2005 a la fecha, se ha generado el curioso fenómeno de recurrir de protección ante la justicia ordinaria, solicitando en ese proceso, de eminente carácter cautelar, la inaplicabilidad de alguna norma ante el Tribunal Constitucional. Por tanto, los roles de ambas judicaturas parecen en realidad complementarse ${ }^{55}$.

Esta situación nos enfrenta a un nuevo problema acerca de la legitimidad democrática del Poder Judicial como "la última palabra" respecto de la interpretación de la Constitución. El reproche acerca del "déficit democrático" del Poder Judicial para resolver asuntos constitucionales no es nuevo, y en todo caso, alcanza también al Tribunal Constitucional, cuyos integrantes tampoco son elegidos mediante votación popular. Obviamente será siempre mejor que exista un tribunal especial, ajeno al Poder Judicial, pero eso no significa que a falta de éste no puedan los jueces ordinarios desplegar esta labor. El Poder Judicial tiene tan poca (o tanta) legitimidad democrática como la tiene el Tribunal Constitucional, y decir que por eso se convierte el control constitucional en un "puro acto de deliberación política" es ignorar el carácter técnico y científico que sin duda tiene la labor jurisdiccional, para lo cual es bueno recordar la réplica de Hans Kelsen a Carl Schmitt acerca de la misma objeción (en ese entonces, Schmitt pretendía concentrar el control constitucional en el Poder Ejecutivo bajo el argumento que se trataba de una labor eminentemente política ${ }^{56}$. Detrás de esta crítica está la idea de que el supremo intérprete de la Constitución debe

53 PICA (2010), p. 332.

54 PICA (2010), p. 349.

55 Así, ocurrió, entre muchos otros casos, respecto del caso del "matrimonio homosexual", en que una pareja del mismo sexo solicitó la celebración de un matrimonio ante el Registro Civil, lo que fue denegado, presentando posteriormente un recurso de protección ante la Corte de Apelaciones de Santiago, en que se solicitó la inaplicación de las normas civiles referidas al matrimonio. Cfr. Silva (2012b).

56 KeLSEN (2009), pp. 365 y 366. 
ser el pueblo, a través de sus representantes democráticamente elegidos, los que, en ejercicio de su mandato, deberán efectuar las modificaciones legales, dictar nuevas leyes o derogar las existentes, que permitan mantener el sistema legal en armonía con la carta fundamental. El Poder Judicial, cuyos miembros no representan a nadie, y a quien nadie controla, no estaría legitimado para dictar "leyes particulares" que sentaran el verdadero sentido y alcance de la Constitución" para cada caso. Críticas similarmente fundadas se han hecho también a la creciente tendencia del "constitucionalismo" de los fallos, que para algunos es una forma de "activismo judicial" 57 , o derechamente una intromisión impropia en materias que son de competencia del poder legislativo ${ }^{58}$.

Estas críticas pueden ser respondidas con varios argumentos. En primer lugar, los miembros del Poder Judicial, sobre todo de las Cortes superiores (lo mismo que los del Tribunal Constitucional) son designados por el poder político, democráticamente elegido, interviniendo tanto el Ejecutivo como el Congreso. El propio Poder Judicial y el Tribunal Constitucional son instituciones creadas en forma democrática, y de todas formas, sustentadas como válidas por buena parte de las democracias occidentales, más allá de la buena o mala opinión que podamos tener de ellas. Pero más allá de la legitimidad democrática de estos tribunales, adhiero en este punto a la idea de Dworkin de que los derechos fundamentales de la minoría estarán siempre mejor resguardados ante un órgano que no depende de forma tan intensa de las mayorías electorales, como es el Poder Ejecutivo y Legislativo; esto, si nos "tomamos los derechos en serio" como dice este autor. $\mathrm{Al}$ mismo resultado arribó Kelsen en su momento, aunque apoyado en argumentos diferentes (contrapeso al poder del Estado). Son, evidentemente, ideas garantistas, de fuerte énfasis en la defensa de los derechos y garantías individuales por encima de los proyectos colectivos y las políticas estatales de apoyo mayoritario en la ciudadanía. Es el último resguardo del ciudadano ${ }^{59}$. Por lo demás, como acota Atienza, el Poder Legislativo argumenta y decide

57 García y Verdugo (2013), pp. 37 y 38, acerca del "activismo judicial" han dicho que, "hay más razones para pensar que los jueces son menos democráticos que los representantes electos...".

58 En este sentido, García y Verdugo (2010), p. 420: "el Tribunal Constitucional chileno ha cobrado especial relevancia en el último tiempo gracias a la dictación de polémicos fallos de trascendencia para el juego político. De esta manera, observamos que un órgano de naturaleza jurisdiccional resuelve asuntos fundamentales de la deliberación colectiva".

$59 \mathrm{Al}$ respecto, SILVA (2010), p. 484, ha dicho que: "la Constitución es una norma autosuficiente, aplicable no sólo con independencia de la ley, sino incluso contra la misma ley". 
de acuerdo a criterios finalistas (lo que debe hacerse en el futuro, las políticas públicas) más que ponderar una situación pasada, y subsumirla a alguna norma o principio. En este sentido, Lovera y Ugarte han dicho "el foro de la razón -las cortes- se impone al de las pasiones - la política-operando bajo una serie de circunstancias que restringen su discrecionalidad (la historia y la integridad en la interpretación), cuestión que les permite ser fieles a los principios fundamentales de la comunidad" 60 . A propósito de la aplicación de principios constitucionales "abiertos" por parte de los tribunales -y no de normas emanadas del legislador democráticamente elegido- Robert Alexy señala que, "el concepto de derecho no positivista niega carácter jurídico sólo en casos de extrema injusticia" 61 , que es precisamente lo que se propone en este trabajo, como quedará claro en los casos jurisprudenciales citados.

\section{Supuesta contravención al principio de inavocabilidad judicial}

Dispone el art. 8 del Código Orgánico de Tribunales: "ningún tribunal puede avocarse el conocimiento de causas o negocios pendientes ante otro tribunal, a menos que la ley confiera expresamente esta facultad"62. Esta objeción es más aparente que real, ya que efectivamente el art. 20 de la Constitución Política (ley suprema de la Nación) admite la intrusión de las Cortes de Apelaciones en asuntos pendientes, incluidos por cierto los procesos judiciales. Por lo demás, es esto precisamente lo

60 Lovera y Ugarte (2010), p. 406. Los mismos autores han dicho, en su trabajo referido a la distinción de reglas y principios en el marco de la justicia constitucional, p. 398: "la cercanía de esta discusión con la relativa a la (i)legitimidad de la revisión judicial de la legislación es evidente. Si los jueces pueden definir cuáles son esos principios - en caso que no se nos aparezcan a la vista-o si son ellos quienes los interpretan con carácter definitivo -cuando están contenidos en la Constitución- entonces la revisión judicial de legislación sólo busca que la producción normativa de nuestro Congreso respete esos principios que otorgan consistencia a nuestra práctica constitucional (en el primer caso), o que nosotros mismos hemos pre-comprometido a respetar (en el segundo). Pero si usted no cree que el derecho se configure sobre la base de reglas más principios-al menos no cuando sólo los jueces puedan identificarlos y definirlos-entonces para usted la justicia constitucional echa por la borda las promesas de auto gobierno para concentrar el poder de los jueces. Funcionarios públicos, es cierto, pero que nadie ha elegido".

61 Alexy (2013), p. 61.

62 Ortúzar (1994), p. 6.; Salas (1990), p. 96, citando el fallo de 6 de julio de 1990, rol No 7838 de la Corte de Apelaciones de Concepción, señala que: "sostener lo contrario significaría transformarlo en un recurso subsidiario o supletorio de los ordinarios y extraordinarios que la ley ha establecido para la regular, expedita y correcta administración de justicia, dando lugar a un paralelismo inaceptable, que incluso atentaría contra la base fundamental de la inavocabilidad que contempla el artículo $8^{\circ}$ del Código Orgánico de Tribunales". 
que hace hoy en día el Tribunal Constitucional a través del recurso de inaplicabilidad. Por lo demás, es inherente a todo control de constitucionalidad el avocarse a revisar sentencias ajenas, sea directamente, sea a través del control normativo indirecto de la inaplicabilidad.

\section{El argumento del imperio del Derecho}

Una tercera objeción, de gran recurrencia en nuestros fallos, dice relación con el argumento de que "toda sentencia emanada de un tribunal competente en un proceso legalmente tramitado no puede ser injusta, ilegal ni arbitraria". Este argumento, conocido como el del "imperio del derecho" es fácilmente rebatible. Evidentemente que no es lo mismo un "proceso" que un "debido proceso", y no se requiere gran esfuerzo para imaginar hipótesis en que un tribunal puede pronunciar una sentencia que sea abiertamente inconstitucional, como los casos que se citan en este trabajo. La legislación peruana antes citada, hace procedente el amparo respecto de sentencias, precisamente cuando éstas no han emanado de un proceso "regular". La profesora peruana Mariella Trujillo entrega una pauta acerca de los procesos irregulares: "(i) la ausencia notoria de notificación judicial al emplazado en un proceso ordinario es a todas luces, a decir de la jurisprudencia nacional, una violación al derecho de tutela judicial efectiva (...) (ii) la tramitación de un proceso judicial ante una autoridad judicial incompetente en razón de materia o función" 63 .

\section{La contravención a la cosa juzgada}

Una cuarta objeción se refiere a la posible vulneración al principio de la cosa juzgada, entendiendo que la sentencia de protección no podría alterar

63 Trujillo (2003), p. 275. Este argumento del "imperio del derecho" es muy recurrido en la doctrina y jurisprudencia. Así, SALAS (1990), p. 94, para desestimar la procedencia del recurso de protección respecto de sentencias judiciales ha dicho que: "corroboraría este juicio la circunstancia de que las resoluciones judiciales se pronuncian, naturalmente, en el curso del desarrollo del proceso, instrumento que de por sí coloca dentro del imperio del derecho la materia respecto de la que incide el reclamo, cumpliéndose en esta manera la finalidad del recurso: restablecer el imperio del derecho". En la reciente sentencia del caso "Inmobiliaria Frontera" (2014), la Corte de Apelaciones de Valdivia resolvió rechazar la protección solicitada, "al emanar los actos recurridos de una resolución judicial dictada por una sala de la Corte de Apelaciones de Temuco, dentro de su competencia y en ejercicio de las facultades que el legislador expresamente le confiere para el conocimiento del recurso de apelación en materia civil, máxime si consta que previo a su dictación el actor pudo ejercer plenamente su derecho a defensa, impugnando la resolución de primer grado, e incluso, deduciendo paralelo a esta acción un recurso de queja en contra de la misma resolución, el cual fue declarado inadmisible por la Excma. Corte Suprema..." 
lo ya resuelto por la resolución que se estima vulneratoria de derechos. ${ }^{64}$. El argumento me parece poco atendible por lo siguiente. Primero, porque la interposición del recurso de protección está acotada en el tiempo, y sólo sería admisible en este caso durante los treinta días siguientes a la notificación de la sentencia agraviante. Si se le compara con la inaplicabilidad, que puede ejercerse en cualquier momento del proceso, mientras exista una "gestión pendiente”, sin duda que la protección ofrece mayores certezas. Por lo demás, la cosa juzgada está constantemente puesta a prueba a través del sistema de recursos procesales, que pueden dejar sin efecto lo resuelto. Incluso a través del recurso de revisión se pueden revocar sentencias firmes y ejecutoriadas. De cualquier forma, la garantía de seguridad jurídica que se vería amagada por la protección, se sacrificaría por evitar o remediar una vulneración constitucional que se estima como más importante. Además, debe tenerse en cuenta que en buena parte de los casos que se analizan en el capítulo siguiente precisamente lo que se denuncia es la inoponibilidad de una sentencia por parte de un tercero ajeno al proceso, sobre la base del efecto relativo de las sentencias que consagra el artículo $3^{\circ}$ del Código Civil. Obviamente que una sentencia inoponible no produce cosa juzgada, por lo que esgrimir ese argumento es incurrir en una petición de principio o circularidad.

\section{Los argumentos formalistas}

Finalmente, está el argumento que denomino "formalista". Ha dicho el mismo Salas que el recurso de protección es "extraño a la ritualidad" de nuestro proceso, y que iría en contra de los principios del procedimiento chileno, que es "riguroso y formal", que "contempla cuidadosamente las etapas del desarrollo de los juicios y lo medios para que durante su curso las partes formulen y prueben

64 Salas (1990), p. 100, en referencia a la sentencia de 7 de septiembre de 1990, rol 7927 de la Corte de Apelaciones de Concepción. Este autor aboga por la consagración a nivel constitucional del principio de cosa juzgada, el que al estar sólo reconocido a nivel legal, cedería frente a las facultades del Poder Judicial de revisar una sentencia por la vía de la protección, como autoriza el art. 20 de la Constitución. A mi entender, tanto el principio de cosa juzgada -como su homólogo penal de non bis in idem-se desprenden de forma inequívoca de la garantía del debido proceso del art. 19 № 3 de la Constitución; o incluso para autores como SERRA (2008), pp. 52-53, es lo que define a la función jurisdiccional, por oposición a la función administradora del Estado, cuya función también es emitir decisiones (pero que no gozan de cosa juzgada). Pero la cosa juzgada no es un principio absoluto, como hemos revisado, y debe ser ponderado con otros valores que pueden ser de mayor relevancia, como es el derecho a defensa de los terceros a quienes afecta el fallo impugnado. 
los fundamentos de sus pretensiones y defensas", que se trata de un "esquema claro y preciso", que el recurso de protección "constituye una perturbación que altera $y$ molesta" 65 . Creo que esta objeción está ya largamente superada desde que se admitió en nuestro derecho la inaplicabilidad por inconstitucionalidad, que produciría las mismas alteraciones denunciadas. En todo caso, y al igual que dije respecto de la seguridad jurídica de la cosa juzgada, la ritualidad del proceso parece como un valor que perfectamente puede ser sacrificado en aras de proteger los derechos fundamentalmente garantizados de una parte que ha sido víctima de una sentencia ilegal o arbitraria.

VII. EL RECURSO DE PROTECCIÓN COMO CONTROL CONSTITUCIONAL DE VULNERACIONES GRAVES COMETIDAS EN UNA SENTENCIA JUDICIAL, EN EJERCICIO DE las facultades Conservadoras del Poder Judicial

Lo que propongo en este trabajo, a la luz de la jurisprudencia que se analiza en el capítulo siguiente, es abrir la posibilidad de que nuestras Cortes de Apelaciones, y en definitiva, la Corte Suprema, revisen la constitucionalidad de las sentencias judiciales civiles, y dejen sin efecto aquéllas en que se han vulnerado en forma grave y notoria las garantías fundamentales de alguna persona. Es este el sentido y alcance que le han dado algunos fallos que han acogido acciones de protección. No es abrir una puerta a una tercera o cuarta instancia, sino simplemente establecer un "dique mínimo" que sirva de freno para ciertas arbitrariedades especialmente graves que pueden cometerse en el proceso civil. Como se verá, una de las más patentes es el pronunciamiento de sentencias y la tramitación de procesos en ausencia de alguno de los involucrados o afectados por la misma.

La función del recurso de protección es cautelar las garantías fundamentales de los ciudadanos, y como he argumentado, no existen razones atendibles que permitan dejar al ciudadano desprotegido cuando es parte en un proceso civil. Los tribunales de justicia -sean parte del Poder Judicial, o bien el Tribunal Constitucional- están llamados a ejercer su poder/deber de jurisdicción, conjuntamente con las facultades conservadoras y nomofilácticas. Pero la primera no es separable de la segunda, al menos no debiera serlo si nos tomamos los derechos de las personas en serio y reconocemos la garantía de la tutela judicial

65 SALAS (1990), pp. 95 y 96. 
efectiva respecto de todos, y se le da preponderancia al ius litigatoris, y no sólo al ius constitutionis ${ }^{66}$. Las facultades conservadoras, consagradas en el art. $3^{\circ}$ del Código Orgánico de Tribunales, entendidas como la debida protección de las leyes, la Constitución y las garantías fundamentales en todas las actuaciones jurisdiccionales, están íntimamente emparentadas con el control de constitucionalidad de las leyes ${ }^{67}$. El recurso de protección en su dimensión "cautelar" no es incompatible con la dimensión "conservadora". Podría pensarse que por su naturaleza, el recurso de protección está llamado a una ponderación rápida y somera de los antecedentes que el recurrente le allegue a la Corte respectiva, en orden a obtener un remedio también pronto a una vulneración de sus derechos. Esta dimensión cautelar, podría verse como contradictoria a un control constitucional de una sentencia judicial, o bien al ejercicio de estas facultades conservadoras. Incluso, si admitimos que es el Poder Judicial el supremo guardián de la Constitución, el recurso de protección -y no la inaplicabilidad- sería una herramienta que por su urgencia sería inadecuada para ese objetivo, máxime si se intenta una interpretación uniforme de los preceptos constitucionales (y resguardar la igualdad ante la ley). En realidad, esta contradicción no es tal. Si el recurso de protección se reserva-como cierta jurisprudencia lo ha hecho- a revisar aquellas violaciones de derechos graves y notorias ocurridas en el proceso o con ocasión de la dictación de una sentencia, parece claro que se cumplirá satisfactoriamente con ambos objetivos, tanto la cautela como el control constitucional. No creo que el recurso de protección deba emplearse para solucionar grandes conflictos de derechos o antinomias subyacentes a un conflicto jurisdiccional. Mi propuesta es más acotada, y sólo para aquellos casos en que no exista otra solución eficaz para la arbitrariedad cometida. En todos los casos en que se requiera una análisis reposado de los antecedentes, existirán los recursos ordinarios, o bien la propia inaplicabilidad ante el Tribunal Constitucional.

66 Bordalí (2007), p. 532, ha dicho que: "si se ha de crear un recurso procesal en manos del Tribunal Constitucional chileno a fin de contribuir a la mayor unidad en la interpretación jurisdiccional de la Constitución $y$ de los derechos fundamentales, creo que debe ser concebido en términos claramente casacionales puros, es decir, como tutela del ius constitutionis y no del ius litigatoris. Esto quiere decir que la solución del caso concreto en materia de tutela de derechos fundamentales deben darla los tribunales de la judicatura ordinaria. El Tribunal Constitucional no debería revisar esa actuación, salvo que afectara su doctrina o jurisprudencia en materia de derechos fundamentales".

67 Cfr. Ortúzar (1994), p. 10. 
Nuestra Constitución proclama que, "el Estado está al servicio de la persona humana". Un poder del Estado, como es el Poder Judicial, o como es el Tribunal Constitucional, no pueden abocarse al control constitucional en forma aséptica, de espaldas a la comunidad, abusando del formalismo y pretendiendo limitar sus facultades conservadoras a inaplicar ciertos preceptos legales a un caso concreto, desentendiéndose del resultado del juicio. Lamentablemente el modelo de Tribunal Constitucional vigente a partir de la reforma de 2005 consagró una forma de "reenvío", que en nuestro sistema no existía ni siquiera para el recurso de casación (ya que es la misma Corte Suprema la que anula y dicta la sentencia de reemplazo), generando un control constitucional que satisface la pretensión estatal de someter a la Constitución el contenido y alcance de las leyes, pero que lamentablemente muchas veces no satisface a las partes del proceso.

Por lo mismo, y tratándose de la protección de los derechos fundamentalmente garantizados de las personas, no me parecen atendibles los argumentos que aluden al "uso racional" del "recurso justicia", desde la óptica del análisis económico del derecho, ni tampoco las previsiones fatalistas de que nos "llenaremos de recursos", como se anticipó (equivocadamente, a mi juicio) respecto de la inaplicabilidad que entró en vigencia en la reforma de $2005^{68}$. Existe un conservadurismo mal entendido en nuestro medio, y se pretende hacer creer que "dejar entrar a la Constitución” al proceso será el comienzo del caos, que nuestras Cortes de Apelaciones se llenarán de recursos, que se utilizará el recurso de protección como una tercera instancia, que los tribunales no darán abasto, que los litigantes obrarán de mala fe invocando vulneraciones inexistentes. Razones que me parecen de menor entidad frente a la parte que ha sido injustamente agraviada, y que prescinden que la justicia está para servir a la persona humana, al ciudadano, y no para despachar rápido el trabajo. Lamentablemente llegará

68 En este sentido, García y Verdugo (2010), p. 435. Este tipo de críticas no me parecen atendibles por varias razones. Como advierte Nieva (2010), porque parten de la base que los litigantes o los representados actúan sistemáticamente de mala fe y con objetivos dilatorios, echando mano a las herramientas procesales que da el sistema. Esto efectivamente ocurre, pero no es la regla general, al menos no en el foro chileno, donde existen mecanismos de fiscalización y sanción que funcionan con bastante eficiencia, a cargo de las Cortes de Apelaciones y los propios juzgados inferiores. Lo otro que no es atendible es que se hable de "costos" y beneficios" cuando existen derechos fundamentales en juego. Sin duda existirán casos en que se instrumentalice esta herramienta, pero no es conveniente a mi juicio implementar políticas públicas sobre la base de asumir un uso abusivo de las mismas. Esta misma previsión fatalista se hizo en su momento respecto de los recursos de protección, y lo cierto es que hoy las Cortes de Apelaciones tramitan y resuelven las solicitudes que se les plantean en forma relativamente rápida y eficaz. 
un momento en que la inaplicabilidad ante el Tribunal Constitucional perderá toda relevancia, y la que eventualmente conserve será muy pequeña.

\author{
VIII. EL EFECTO DE COSA JUZGADA DE LA SENTENCIA \\ QUE ACOGE UN RECURSO DE PROTECCIÓN RESPECTO DE UNA \\ SENTENCIA JUDICIAL VULNERADORA DE DERECHOS
}

Finalmente, un tema de importancia: ¿produce efecto de cosa juzgada la sentencia que acoge un recurso de protección respecto de la sentencia judicial que se pronuncie sobre el fondo? El tema ha sido debatido en la doctrina ${ }^{69}$; en todo caso, tratándose de sentencias judiciales, el problema se simplifica bastante, porque el recurso de protección es finalmente "la última palabra" respecto del sentido y alcance de la sentencia que se impugna, con el agregado que es pronunciado -en la gran mayoría de los casos- por la propia Corte Suprema, superior jerárquico de todos los tribunales ordinarios. Pero existe evidentemente una complejidad: dado el carácter cautelar del recurso de protección, podría darse el caso que la Sala Constitucional de la Corte Suprema emita un pronunciamiento, por ejemplo, respecto de la inconstitucionalidad de una medida precautoria dictada en un proceso civil, proceso que culmina posteriormente con un fallo de la Sala Civil de la Corte Suprema, que pronunciándose sobre el fondo, llega al resultado vulnerador que el recurso de protección quiso evitar ${ }^{70}$. Alejandro Romero se hace cargo del problema, pero

69 Romero (2011) pp. 133-144. El análisis de este autor es interesante, y aunque critica la distinción entre cosa juzgada formal y material (crítica que comparto), utiliza estas categorías en su análisis. En mi opinión, la sentencia de protección produce sin duda cosa juzgada material y formal. En el caso "Adriana Vinet" (1998), la Corte de Apelaciones de Concepción rechazó un segundo recurso de protección respecto de los mismos hechos que ya habían sido materia de otra acción de protección anterior. Citó esa Corte un fallo de la Corte Suprema en el sentido que: "la sentencia que se dicte en un recurso de protección, en principio no produce cosa juzgada absoluta, sino que produce cosa juzgada formal, vale decir una firmeza que sólo impide que se incoe otro recurso de protección con las mismas identidades de personas, causa de pedir y cosa pedida, pero no obsta para que se recurra a las vías ordinarias a fin de que en el debido proceso se esclarezcan los derechos en forma definitiva". En realidad, el fallo lo que hace es consagrar una cosa juzgada ciertamente material pero con un efecto relativo; o sea, impide nuevos recursos de protección sobre el mismo asunto pero no una discusión ulterior sobre el fondo. La cosa juzgada formal, como la entiende mayoritariamente la doctrina (sólo por dar un ejemplo, está el trabajo de De La Oliva Santos (2005), p. 97) concibe la cosa juzgada formal como sólo vinculante dentro del proceso para el tribunal que pronunció la sentencia.

70 PARedes (2012), pp. 160-162 advierte que el problema es más aparente que real, ya que si bien la sentencia de la protección produce el efecto de cosa juzgada formal, "en la práctica el recurso de protección cierra para siempre la discusión procesal". 
a mi juicio no llega a una solución correcta. Dice que: "si se dicta una sentencia en un recurso de protección, lo alli decidido puede ser dejado sin efecto al fallarse una acción ordinaria cuya sentencia produzca cosa juzgada sustancial (v. gr., la reivindicatoria, la declarativa del dominio); en cambio, en la situación inversa el efecto de cosa juzgada producido en un juicio de lato conocimiento debe llevar a que no se puede fallar el recurso de protección, ya que existe una decisión sobre el tema que impide pronunciarse sobre el fondo de la acción de protección"71. Romero parece ver en el recurso de protección una suerte de medida cautelar ${ }^{72}$, que no impide que el juez del fondo finalmente falle algo distinto, y lo que defiende en buenas cuentas es que el juez del fondo aplicando la ley civil pueda llegar a una solución contraria e incompatible con lo fallado en el respectivo recurso de protección previo (control constitucional); o sea, que la aplicación de la ley prevalecería frente a la vulneración de garantías fundamentales constatada previamente. Esta solución no parece aceptable. Y tratándose de un recurso de protección en contra de sentencias judiciales tampoco es sostenible que el juez del fondo llegue a una solución incompatible al pronunciar la sentencia definitiva, respecto del control de constitucionalidad previo (respecto de la misma sentencia, o de otra en el mismo proceso); no sólo por lo que ya hemos dicho referido a la supremacía de la Constitución frente a la ley, sino porque efectivamente la sentencia que acoge un recurso de protección produce cosa juzgada material. Es decir, previene que sentencias posteriores -en el mismo o en otros procesos- contradigan o lleguen a soluciones incompatibles con lo declarado por las cortes superiores ejerciendo esta tutela de garantías. Esto, entendiendo por superadas las categorías de la "triple identidad", y aludiendo más bien a un principio de coherencia general del proceso ${ }^{73}$. Por lo mismo, la "última

71 Romero (2011), p. 140.

72 Marín (2014), pp. 95-103, trata el recurso de protección dentro de su tratado sobre medidas cautelares, sólo a efectos de denunciar la utilización de esta vía tutelar constitucional como sucedáneo de las cautelares civiles que contempla el Código de Procedimiento Civil. Las conclusiones a las que llega Romero (2011) parecen contradecirse con el carácter "no cautelar" que le asignó al recurso de protección en un trabajo posterior (Romero (2014), p. 170). De La Oliva Santos (2005) p. 124, al igual que buena parte de la doctrina, estima que las medidas cautelares, por su naturaleza eminentemente provisoria, sólo producen una cosa juzgada formal en la medida que no varíen las circunstancias fácticas que motivaron su concesión. Como forma de cautela, existe la tendencia doctrinal y jurisprudencial de denegar el efecto de cosa juzgada a la sentencia que se pronuncia sobre un recurso de protección, olvidando el especial contenido constitucional de este proceso.

73 Cfr. Nieva (2006) y Carretta (2013). 
palabra” del caso la tendrá la Sala Constitucional y no la Sala Civil de la Corte Suprema. Los problemas más interesantes se producirán cuando existan dos o más sentencias referidas a acciones constitucionales respecto de los mismos o similares hechos, y sobre todo, cuando alguna de esas sentencias acoja la tutela y otras no, lo que será un importante desafío para la doctrina ${ }^{74}$.

En el caso que planteaba al comienzo: la Sala Civil de la Corte Suprema está obligada a llegar a una solución coherente con la decisión adoptada por la Sala Constitucional respecto del recurso de protección acogido respecto de una medida precautoria pronunciada en el mismo proceso. Lamentablemente, tratándose de un fallo de casación emanado del Máximo Tribunal, se hace inviable recurrir en contra de ella, en el evento que incurriera en contradicciones.

\section{ANÁLISIS JURISPRUDENCIAL}

EL RECURSO DE PROTECCIÓN COMO CONTROL DE SITUACIONES PARTICULARMENTE GRAVES DE INCONSTITUCIONALIDAD

A continuación quiero pasar a revisar cierta jurisprudencia de los últimos veinticinco años, enfocado en aquellas sentencias que han recogido las ideas expresadas anteriormente, $\mathrm{y}$ han admitido que es posible recurrir de protección en contra de una sentencia judicial. En el trabajo de Ortúzar que he citado, este autor dijo que, "no conozco ningún constitucionalista o estudioso que sostenga la tesis que el recurso de protección no procede contra las resoluciones judiciales. Por el contrario, todas las que conozco sostiene su procedencia"75. Como he dicho, esta postura hoy es minoritaria. Este autor recopiló alguna jurisprudencia de comienzos de la década de 1990 que acogió efectivamente esa postura, la que aparentemen-

74 El caso "Sindicato de Trabajadores Catedral" (2005) es paradigmático en este aspecto. Se trató de un recurso de revisión ante la Corte Suprema (art. 810 del Código de Procedimiento Civil) en contra de una sentencia de ese Máximo Tribunal, que había acogido un recurso de protección intentado por la empresa empleadora en contra de una resolución de la Inspección Provincial del Trabajo, declarándola contraria a la Constitución. Se alegó por el sindicato recurrente que previo a esa protección, la misma empresa empleadora había intentado un recurso de amparo económico (ley No 18.971) en contra de la misma resolución, resuelto también por la Corte Suprema, que había respaldado a la referida Inspección y la resolución por ella emitida (o sea, había rechazado el amparo). El sindicato alegó que existía en este caso un "colapso de sentencias", ya que parecía incongruente que la misma Corte Suprema rechazara primero un amparo económico, y luego acogiera un recurso de protección, ambos intentados por la misma empresa empleadora en contra de la misma resolución administrativa. La Corte rechazó la revisión argumentando que la primera negativa al amparo económico sólo había producido una cosa juzgada "formal", o sea dentro del proceso, pero no "material", es decir, "no tiene efectos fuera del proceso en que dictó la respectiva sentencia".

75 Ortúzar (1994), p. 10. 
te no se replicó en las décadas siguientes, y cita entre otros fallos, los del caso "Cailliaux" (1994), y "Banco de Santiago" (1994), ambos fallados por la Corte Suprema, como ejemplos de una tendencia jurisprudencial que en ese entonces se avizoraba como favorable a admitir este amparo en sede de protección. En el caso "Caillaux" (1994) se resolvió a favor de un recurrente que no había sido parte en un proceso judicial en que se había pronunciado una sentencia alterando una inscripción conservatoria de dominio, en perjuicio de los recurrentes, decisión que a juicio de la Corte significó una vulneración grave del principio de relatividad de los efectos de las sentencias (art. 30 del Código Civil)". En el caso "Banco de Santiago" (1994) esta entidad financiera había adquirido parte de la cartera de créditos hipotecarios del entonces existente Banco Unido de Fomento. Uno de los deudores había demandado al cedente la extinción del crédito, pero no al nuevo acreedor, el Banco de Santiago, siendo ésta declarada por sentencia judicial. La Corte Suprema acogió el reclamo del banco, sobre la base de que la resolución que acogió la extinción del crédito implica hacer "soportar el imperio jurisdiccional a quien no ha sido parte en el pleito en que se dictó la sentencia que constituye la causa de aquél, por lo que semejante proceder se muestra abiertamente ilegal".

En el caso "Sociedad Agroindustrial Blanqueado" (1996) la Corte Suprema revocó una sentencia de la Corte de Apelaciones de Santiago que había rechazado un recurso de protección en contra de la jueza del $5^{\circ}$ Juzgado Civil de Santiago, quien había ordenado el lanzamiento de un arrendatario que ocupaba un inmueble adjudicado en un remate judicial, del que no había sido parte el arrendatario. La Corte declaró ilegal la sentencia por cuanto lo que debió hacer el adjudicatario era haber solicitado la restitución del inmueble en juicio sumario por extinción del derecho del arrendador. Lo anterior, porque no es lícito que se afecte a un tercero que no ha sido parte en el proceso. Así, se dejó sin efecto el referido lanzamiento. En el caso "Forestal Cholguán S.A." (1997), la Corte Suprema estimó como arbitraria una resolución del Primer Juzgado Civil de Chillán, que en un proceso ejecutivo ordenó la entrega material de ciertos inmuebles al ejecutante, en circunstancias que el propietario de los mismos no sólo no había sido parte en el proceso "sino que ni siquiera fue oído al no tener conocimiento del mismo", declarando su inoponibilidad al recurrente. En el caso "Ramírez Necochea" (1997), la Corte Suprema, revocando una decisión de la Corte de Santiago, acogió un recurso de protección intentado por un recurrente que había adquirido un inmueble en el tiempo intermedio entre que había sido declarado como bien familiar por sentencia judicial (en un proceso en que no había sido parte) y el momento en que se intentó ejecutar dicha sentencia. El 
marido había vendido el inmueble declarado bien familiar a este tercero; sin embargo, al no ser este último parte en el proceso en que dicha declaración tuvo lugar, la Corte Suprema estimó que la misma no le era oponible y no podía ser inscrita en el registro conservatorio.

Un caso curioso es el de la "Municipalidad de Arica" (1997), la cual recurrió de protección en contra del embargo decretado por un juez del trabajo en contra de una serie de inmuebles de propiedad municipal, que según la Ley Orgánica de Municipalidades son inembargables. El embargo había sido decretado en un juicio laboral iniciado por un grupo de docentes municipales en contra del municipio. La Corte de Apelaciones de Arica declaró inadmisible el recurso, pero en ejercicio de sus facultades de oficio, de todas formas dejó sin efecto el embargo. La Corte Suprema posteriormente revocó esa sentencia, declarando como "inapropiado el procedimiento de oficio seguido en primera instancia". Como diré después, este caso presenta la particularidad de haber acogido una protección intentada por una de las partes del proceso.

Gastón Gómez reconoce la reticencia de los tribunales superiores de admitir a tramitación esta protección, salvo respecto "de aquellas resoluciones judiciales que causan agravio o lesión a los derechos fundamentales de terceros que no son parte en el proceso en que ellas -las resoluciones- se dictaron, de modo que a raiz de ello, el afectado o lesionado no ha sido oído al dictarse la resolución ni tampoco ha podido ejercer los medios de defensa de sus derechos. En estas circunstancias, las Cortes con bastante continuidad han aceptado tramitar y en definitiva han acogido recursos de protección". $76 \mathrm{El}$ autor alude a varios fallos, que en su gran mayoría corresponden efectivamente a sentencias de cortes de apelaciones que acogieron los recursos de protección, aunque posteriormente la Corte Suprema finalmente los rechazara vía apelación. A continuación revisaré algunos de ellos.

En el caso "Patricia Wohlk" (2002), la Corte de Apelaciones de Concepción acogió un recurso de protección intentado por la arrendataria de un inmueble en contra del juez del Primer Juzgado Civil de Talcahuano, que había decretado una medida precautoria que autorizaba a la cónyuge del ocupante de una propiedad su reintegro al hogar común. La Corte ponderó las circunstancias del caso, en especial que la cónyuge había abandonado el hogar común seis meses antes de haberse decretado la medida, y sobre todo, que en el tiempo intermedio el cónyuge vivía con otra mujer -la recurrente- a quien había arrendado

76 Gómez (2008), pp. 26 y 27. 
el inmueble. La Corte de Concepción decretó una "medida de protección" consistente en que la cónyuge debía hacer abandono de la propiedad, junto con los hijos. Las particulares circunstancias del caso posiblemente motivaron a la Corte Suprema a revocar más tarde el fallo, aludiendo a la existencia de otros medios de impugnación respecto de la sentencia que había decretado la medida precautoria.

En el caso "Edwin Wohlke" (2003) sucedió lo inverso: la Corte de Apelaciones de Puerto Montt en primera instancia rechazó el recurso de protección (por extemporáneo), para terminar la Corte Suprema acogiéndolo, posiblemente apoyado por un voto de minoría que venía de primera instancia. La Corte Suprema declaró como arbitraria una sentencia del Primer Juzgado Civil de Puerto Montt, que afectó la inscripción de propiedad sobre un inmueble del recurrente, "afectando derechos de terceros quienes no tomaron oportuno conocimiento de la misma, lo que impidió hacer valer sus derechos, vulnerándose la garantía consagrada en el artículo $19 N^{\circ} 24$ ", considerando especialmente que la sentencia recurrida había anulado una anterior, dictada dos días antes, en que se ordenaba informar al Conservador de Bienes Raíces de Puerto Montt acerca de la procedencia de la inscripción solicitada, informe del que inexplicablemente se prescindió al resolver. La Corte Suprema incluso ordenó una anotación en la hoja de vida de la magistrado del juzgado de letras aludido.

En el caso "Inversiones Metalpar S.A." (2003), la Corte de Apelaciones de Concepción, en un fallo de primera instancia, dejó sin efecto una sentencia del Primer Juzgado de Letras de Coronel que había ordenado la incautación de un bus de propiedad de la recurrente (incautación que se había ejecutado), por haber afectado los derechos de un tercero ajeno a un juicio de cobro de impuesto territorial, la que luego, sin embargo, fue dejada sin efecto por la Corte Suprema sobre la base del argumento del "imperio del derecho" ya aludido.

En el caso "Henríquez Japke” (2003), la Corte Suprema terminó acogiendo un recurso de protección originalmente denegado por la Corte de Puerto Montt. En este caso, se recurrió en contra de una resolución del Primer Juzgado Civil de Puerto Montt que había ordenado una inscripción especial de herencia sobre un inmueble, a pesar de existir un informe previo del Conservador de Bienes Raíces de esa ciudad que desaconsejaba dicha inscripción. En el caso, existía una doble inscripción sobre el mismo inmueble, una de ellas más antigua y que había sido el resultado de un antiguo proceso (del año 1957) zanjado por la Corte Suprema. El tribunal de Puerto Montt decidió ordenar una inscripción especial de herencia que emanaba de la segunda y más nueva inscripción, lo que a juicio de la Corte 
Suprema constituía un acto arbitrario, toda vez que se requeriría de un juicio ordinario en que él debe sostener la carga de la prueba.

En el caso "Rolf Eicher" (2004), la Corte de Apelaciones de Puerto Montt rechazó un recurso de protección, en que el recurrente era un tercero afectado por una sentencia judicial que cancelaba una inscripción sobre un inmueble, emanada de un proceso en que no había sido parte y no había podido defenderse (en este caso, se trató de un procedimiento no contencioso). La Corte Suprema en una curiosa solución, declinó pronunciarse sobre la apelación, pero igualmente resolvió anular todo lo obrado por el juez de primera instancia, haciendo uso del art. 84 del Código de Procedimiento Civil, al estimar que, "la naturaleza de la petición de cancelación de inscripción de fojas 13 del expediente traido a la vista, no se condice con el procedimiento voluntario utilizado para ese fin (...) lo que debe ventilarse en un procedimiento de lato conocimiento, con intervención de todos los interesados a quienes afectará lo resuelto".

En el caso "Juan Giacaman y Compañía Limitada" (2004), la Corte de Apelaciones de Concepción acogió el recurso de protección intentado por un tercero a un juicio laboral, que se vio afectado por una resolución judicial del Primer Juzgado del Trabajo de esa ciudad, que ordenó el embargo de un local comercial del recurrente, en un proceso en que no había sido parte. Sin embargo, la Corte Suprema terminó por rechazar el recurso, aduciendo al argumento "de imperio" referido en el capítulo anterior.

Rodolfo Figueroa consigna un caso de un recurso de protección respecto de una resolución judicial, en su obra sobre el Derecho a la privacidad, que fue originalmente acogido por la Corte de Apelaciones de Valparaíso, aunque luego rechazado por la Corte Suprema, cuando se trató de dejar sin efecto una resolución de un Juez de Familia que admitió como prueba unos correos electrónicos, en el caso "Paula Anguita Ramírez" (2008)77.

Finalmente, en el caso "Pedro Vara Parra" (2006), la Corte de Apelaciones de Puerto Montt acogió un recurso de protección deducido contra una sentencia del Segundo Juzgado de Policía Local de esa ciudad, que había concedido la renovación de la licencia de conducir del recurrente, pero condicionando

77 FigueroA, Rodolfo (2008), pp. 304-311: “...el criterio de la Corte de Apelaciones de que un recurso de protección no puede ser ocasión para interferir en otro procedimiento judicial bajo la dirección de un juez competente. Este asunto amerita análisis (...). Esto es asi desde el punto de vista procesal, pero resulta cuestionable desde la perspectiva constitucional: el articulo 20 de la Constitución permite a las Cortes adoptar cualquier medida que estimen pertinente para resguardar derechos fundamentales. Esta norma ciertamente ha de poder aplicarse con preeminencia sobre las normas procesales de rango legal". 
una futura renovación a que no incurriera en nuevas faltas durante un año y medio, prerrogativa que la ley no le concede a esos jueces. Dijo esa Corte que, "es claro que la competencia del juez de la causa se agota necesariamente al resolver el reclamo respectivo y no puede en caso alguno agotar su actuar y consecuencialmente condicionar con ello la resolución de futuros reclamos". La Corte Suprema finalmente rechazó el recurso, acogiendo una apelación, sobre la base del "argumento de imperio".

Como queda claro de los dos últimos casos, se trata de protecciones concedidas a favor de partes en el proceso en que se pronunciaron las resoluciones atentatorias de garantías constitucionales.

Sin embargo, en la gran mayoría de los fallos posteriores no es posible encontrar sentencias que acojan recursos de protección en contra de sentencias judiciales, aunque hay que decir que los hechos subyacentes a los casos revisados son diferentes de los que sirven de sustento a los casos en que se han acogido ${ }^{78}$.

78 De la jurisprudencia revisada: el caso "Mirna Sepúlveda Arias" (2008), en que tanto la Corte de Apelaciones de Talca como la Corte Suprema rechazaron una protección referida a una sentencia que rechazó la excepción de "no empecerle la sentencia" opuesta por la recurrente, tercera ajena a un juicio de reivindicación de un inmueble que sería de su propiedad, atendido a que se estimó que de acogerse se convertiría la protección en un "recurso subsidiario" a los ordinarios que ya existen; en el caso "Magaly Contreras Romero" (2008), tanto la Corte de Punta Arenas como la Corte Suprema denegaron una protección entablada contra un fallo del Tribunal de Familia de esa ciudad que concedió el cuidado provisional de los hijos de la recurrente al padre de los mismos; asimismo, la Corte de Apelaciones de Santiago rechazó el recurso de protección intentado por la diputada Claudia Nogueira en el caso "Claudia Nogueira Fernández (2009)", en contra de una sentencia del Tercer Juzgado de Garantía de esa ciudad que ordenó el levantamiento del secreto bancario respecto de la recurrente, titular de una cuenta bancaria bipersonal con su cónyuge, alcalde de la comuna de Recoleta, quien estaba siendo investigado criminalmente; la Corte de Apelaciones de Valparaíso rechazó también el recurso de protección intentado en el caso "Rosemarie Weber Paulus" (2010), en que la recurrente, demandada en un juicio civil, alegó una vulneración de su derecho a la intimidad respecto de una exhibición de documentos decretada mediante sentencia dictada por el Tercer Juzgado Civil de Viña del Mar; en el caso "Papelera Nacional Limitada" (2013), el recurrente impugnó una sentencia de un juez árbitro que había decretado una medida precautoria de prohibición de celebrar actos y contratos sobre un inmueble de su propiedad, alegando que lo obrado por el árbitro (en un proceso en que no había sido parte) había sido declarado nulo con posterioridad a la sentencia que decretó la precautoria. Una de las razones para el rechazo, según razonó la Corte de Apelaciones de Santiago, fue que el recurrente se había adjudicado el inmueble "cuando ya se encontraba inscrita la medida que se ataca". La Corte Suprema confirmó este rechazo, con un voto disidente de ministro Sr. Pfeffer "quien estuvo por revocarla y acoger el recurso de protección para el solo efecto de decretar el alzamiento de la medida precautoria que afecta a un tercero, desde que el árbitro recurrido, al dictar el respectivo cúmplase de la resolución que anuló todo lo obrado en el procedimiento, debió explicitar que quedaba sin efecto también la medida precautoria por él decretada, habida consideración que su existencia afecta a un tercero; la Corte de Apelaciones de Valdivia rechazó el recurso de protección intentado en el caso "Sociedad Maderera Vásquez Hermanos Limitada" (2013), en que la recurrente se vio impedida de 
La excepción la hace el caso "Daniel Medina Berrocal” (2009), en que la Corte de Apelaciones de Valdivia acogió un recurso de protección intentado por un defensor público en contra de una sentencia del Juzgado de Garantía de Valdivia que lo había suspendido del ejercicio de la profesión, como sanción por haberse retirado de la sala de audiencias. La Corte de Valdivia entendió que el juez de garantía había actuado fuera de su competencia legal al aplicar una sanción que sería privativa del abandono de la audiencia de juicio oral, aunque la Corte Suprema posteriormente terminó por rechazar el recurso, con un voto disidente. Como se aprecia, en este caso el recurrente no es propiamente una parte ajena al proceso.

De la jurisprudencia recopilada y expuesta, se aprecia una notable inclinación a que las Cortes superiores concedan la protección a favor de terceros ajenos al proceso, que se han visto afectados por una sentencia judicial. Ello no significa que el recurso de protección se circunscriba sólo a esos casos. En la jurisprudencia de los casos "Municipalidad de Arica" (1997), "Paula Anguita Domínguez" (2008), "Pedro Vara Parra” (2006) y "Daniel Medina Berrocal” (2009) ya citados se aprecia que fueron las partes quienes recurrieron y a quienes se les amparó en sus derechos violentados en un fallo judicial. De todas formas, de lege ferenda, sería conveniente la discusión y diseño de un mecanismo procesal que consagrara positivamente la impugnación de tercetos ajenos al proceso, como existe en los Códigos de procedimiento civil francés e italiano ${ }^{79}$, y asimismo, que se reconociera

retirar materialmente unas maderas adquiridas a un tercero, como consecuencia de una medida prejudicial precautoria decretada por el Juez de Letras de Los Lagos, que impedía celebrar actos y contratos sobre el predio en que estaban las maderas, en el marco de un juicio sumario en que el vendedor era el demandado. Hay que decir que la Corte tuvo en especial consideración que el recurrente no acompañó el contrato de compraventa de maderas al que aludió en el recurso, y la existencia de una apelación pendiente respecto de la medida precautoria ante la misma Corte; la Corte de Apelaciones de Concepción rechazó el recurso de protección del caso "Luis González del Valle" (2014) intentado contra el tesorero Provincial del Biobío, actuando como juez tributario, quien había ordenado una medida precautoria de prohibición de celebrar actos y contratos sobre un vehículo de su propiedad, y el embargo de sus remuneraciones, en un proceso de cobro ejecutivo de impuestos, que se mantuvo paralizado entre los años 1998 y 2013, impidiéndole de esa forma alegar la prescripción extintiva o el abandono del procedimiento; la Corte de Apelaciones de Talca rechazó también el recurso de protección en el caso "Constructora Luis Navarro S.A." (2014) respecto de una sentencia de un juez civil de esa ciudad que había decretado una medida precautoria de retención de dineros en un juicio civil en que efectivamente era demandada la recurrente, aunque según ésta no se daban los presupuestos legales para su concesión.

79 Esta posibilidad de impugnación tampoco existe en el ordenamiento español, a pesar de lo cual NiEVA (2006), p. 213, sugiere su incorporación en los siguientes términos: "Creo que existe aquí una evidente laguna, que debiera haber sido integrada en la Ley de Enjuiciamiento Civil introduciendo en nuestro ordenamiento un 
expresamente el debido proceso en toda su extensión como un derecho garantizado por esta acción constitucional. Mientras ello no ocurra, el recurso de protección se abre paso como el control de constitucionalidad mediato de una garantía que paradójicamente no está abarcada por esta acción constitucional, como es el debido proceso del art. 19 No 3 de la Constitución (salvo en lo referido al derecho al juez natural), aludiéndose a la protección del derecho de propiedad como bien jurídico afectado, solución que ciertamente no es la dogmáticamente adecuada, como lo ha denunciado la doctrina ${ }^{80}$.

\section{El PROCESO CIVIL NO PUEDE PERMANECER AISLADO \\ A LA TENDENCIA ACTUAL DE CONTROL CONSTITUCIONAL}

Hasta que no entre en vigencia el nuevo Código Procesal Civil y su recurso extraordinario, el control constitucional de los fallos civiles quedará al arbitrio de la interpretación de la sala constitucional de la Corte Suprema. A primera vista, puede parecer que la justicia civil ha sido abandonada, y hoy aparece como un vetusto caserón en medio de un barrio en que todas las casas han sido demolidas y dado paso a modernos edificios. El proceso civil parece así atrapado en medio de un sistema inorgánico e injusto, que genera decisiones jurisprudenciales que parecen estar fuera del alcance de la Constitución Política, a diferencia de la justicia especializada, que es objeto de controles amplísimos en sus actuaciones procesales. Podría pensarse que esta diferencia no es arbitraria, y que obedece a un propósito deliberado, o al menos, como la consecuencia coherente de una serie de reformas procedimentales independientes: puede decirse que en el proceso penal, laboral y tributario sí existe un ciudadano que

medio de impugnación similar a la "oposición de terceros" de los derechos francés e italiano (...) plantea especial interés la tierce opposition francesa, que abre la posibilidad a un tercero perjudicado por una resolución judicial, de que solicite la revisión de dicha resolución por el mismo juez que la dictó, teniendo en cuenta que el anterior proceso fue sustanciado sin él. De este modo, el Juez volverá a juzgar los puntos que le señale el tercero, como si, de hecho, estuviera completando el proceso ya celebrado con los argumentos que ahora le da el tercero. El plazo para plantearla es, normalmente, de treinta años desde la fecha de la sentencia, y de dos meses si la sentencia le hubiere sido notificada al tercero".

80 Resulta en realidad paradójico que la garantía constitucional del debido proceso no goce de una acción judicial directa que la tutele, debiendo recurrirse por la vía de la casación, a través de algunas de sus concreciones legales en las causales de casación en la forma; o bien, por la vía del recurso de protección, debiendo recurrirse a través del eufemismo de "afectación del derecho de propiedad" u otra vía mediata. Sobre la "propietarización de los derechos", ver PAREDEs (2012), pp. 157-158. El tema en todo caso no es pacífico en el Derecho comparado, y como se aludió anteriormente, NIEVA (2003) aboga por su protección directa a través de la casación civil. 
está en profunda asimetría con otro (Ministerio Público, empleador, el Fisco), situación que es el ambiente propicio para generar toda clase de vulneraciones en las garantías fundamentales. Esta profunda asimetría en el proceso civil parece desaparecer, precisamente por ser el lugar de encuentro de partes que se estiman como iguales. Sin perjuicio de que efectivamente la justicia especializada penal, laboral o tributaria pueda conocer de casos en que se requiera la tutela de los derechos de la parte "débil", ello no significa que en el marco del proceso civil ello no suceda, como por ejemplo, en el administrativo sancionatorio, que aún es competencia de los tribunales ordinarios. Una sentencia civil -auto, decreto, interlocutoria o definitiva- puede constituir un acto de autoridad vulnerador de los derechos fundamentalmente garantizados de una de las partes o de terceros. Así lo comprueba la jurisprudencia de los últimos veinticinco años que se analizó en este trabajo, a propósito del recurso de protección. Y así lo ha entendido, por ejemplo, la legislación española que desde hace años contempla la posibilidad de solicitar la tutela de derechos fundamentales vulnerados en un fallo civil, a través del recurso de amparo.

No existe, a mi juicio, razón valedera alguna -al menos que se haya explicitado- para marginar del control constitucional a las sentencias emanadas de los tribunales civiles. Sí existe un "mito" muy extendido, de que los conflictos civiles no son asuntos de debate constitucional, lo que es un profundo error. Así, Jordi Delgado decía a propósito del requisito de "interés general" del recurso extraordinario que se propone en el proyecto de Código Procesal Civil, que "parece muy complejo encontrar un interés común a los ciudadanos en la resolución de un litigio generado por el impago de una renta en un contrato de arrendamiento"81. Si concebimos el proceso civil como un receptáculo de cobranzas judiciales masivas o de cobro de rentas de arrendamiento, efectivamente el control constitucional parece sobrar. Pero lo cierto es que el proceso civil conoce de asuntos ciertamente mucho más complejos e importantes, y en realidad, es el proceso originario o residual, que se aplica cuando no existe ningún otro procedimiento aplicable. Su importancia es, por tanto, fundamental. A este respecto, Enrique Barros tiene también una postura conservadora, y dice que "lo cierto es que la generalidad de las disposiciones constitucionales requiere para su concreción de los conceptos e institutos del derecho privado" 82 y avala la jurisprudencia de la Corte

81 Delgado (2012), p. 137.

82 Barros (2008), p. 251. 
Suprema en orden a inadmitir los recursos de casación en el fondo en que se denuncie la infracción de una norma constitucional, omitiendo el recurrente señalar qué norma de rango legal -que concrete el principio constitucional- ha sido vulnerada. Dice también este autor que, "el riesgo es que el derecho constitucional devenga en una forma imprecisa de orden público que limita las potestades fundadas en el principio de autonomía privada", aunque admite que "no se puede ignorar que, al menos en casos extremos, el principio de igualdad puede establecer limitaciones a la autonomía privada" 83 . Son precisamente este tipo de prejuicios los que han mantenido a la jurisdicción civil fuera del ámbito del control constitucional en Chile. No sólo el principio de igualdad -como señala Enrique Barros- puede ser un límite a la autonomía privada. También el principio de dignidad mínima de todo ser humano aparece como un principio inclaudicable frente a otros derechos particulares, principio que debe ser "tomado en serio", siguiendo la tesis de Ronald Dworkin, o debe ser ponderado como "de mayor peso" que cualquier otro, según la fórmula de Robert Alexy. En suma, se trata de definir hasta dónde el sistema estará dispuesto a dar supremacía a los derechos de la minoría frente a las garantías de que disfruta la mayoría amparadas por una ley democráticamente sancionada.

Un proceso civil no es en absoluto un terreno aséptico a la "contaminación constitucional". En todo juicio civil está envuelto un conflicto de principios, una afectación de derechos, el sacrificio de derechos ajenos, y la prevalencia de los de una de las partes. Estos conflictos pueden resolverse recurriendo a la legislación civil, pero existirán muchos casos en que las categorías dogmáticas civiles estarán rebasadas, serán insuficientes o no habrán previsto el conflicto sometido a conocimiento del juez. El constitucionalismo de los derechos -incluido el Derecho civil- provee una poderosa herramienta para la solución de problemas recurriendo a la argumentación jurídica y el empleo de fórmulas como las mencionadas más arriba. Las lagunas normativas y axiológicas muchas veces sólo pueden ser llenadas con la alusión a los derechos fundamentalmente garantizados a las partes, y no sólo-como advierte Barros- en temas de libertad de expresión o en que el principio de igualdad esté comprometido ${ }^{84}$. El admitir a la Constitución como fuente válida de Derecho aplicable al caso civil -y

83 Barros (2008), p. 254.

84 NúÑEZ, José Ignacio (2012), p. 527. 
controlable ex post en la sentencia de término- permitirá arribar a soluciones menos arbitrarias y más justas.

Enrique Barros dice que, "finalmente, no es usual que las normas de derecho privado estén en conflicto con el ordenamiento constitucional" 85 . Pero aquí no se trata sólo de que las normas civiles no estén confrontadas con la Constitución, sino que las sentencias mismas de los tribunales civiles estén acorde a la Carta Fundamental. No es suficiente el control de constitucionalidad ex ante del Tribunal Constitucional (respecto de las normas), sino que será necesario contar con un último dique que detenga las arbitrariedades cometidas en las sentencias mismas (ex post), se haya o no aplicado una norma que adolezca de inconstitucionalidad. Por todo esto, parece insostenible e irrazonable la situación actual, de férreas restricciones al control de constitucionalidad de las sentencias civiles.

\section{CONCLUSIONES}

1. En el ordenamiento jurídico chileno coexisten los controles de constitucionalidad a cargo del Tribunal Constitucional y a cargo de los tribunales ordinarios que son parte del Poder Judicial. Mientras el primero ejerce un control ex ante, respecto de las normas que posiblemente se aplicarán a un caso concreto que tiene gestiones pendientes ante un juez ordinario, los segundos ejercen un control directo respecto de resoluciones y actuaciones judiciales, y por lo mismo, ex post.

2. En este panorama, no existe un reconocimiento a nivel legal -y sólo tímidamente a nivel jurisprudencial- de la posibilidad que las sentencias pronunciadas en sede civil sean revisadas en su constitucionalidad. Esta situación contrasta con la jurisdicción especial en materia laboral, penal y tributaria, en que sí es posible reclamar una tutela respecto de actos desplegados por la judicatura, generando una odiosa y arbitraria diferencia.

3. El recurso de inaplicabilidad por inconstitucionalidad ha demostrado ser una vía de impugnación ineficaz para obtener el amparo frente a vulneraciones de los derechos fundamentales. Esto, porque los pronunciamientos del Tribunal Constitucional no son la "última palabra" en el proceso, la que queda reservada para el tribunal ordinario que conoce del asunto, y que muchas veces arriba a soluciones que son igual de gravosas que la que el recurrente de inaplicabilidad quería evitar, aun habiendo obtenido una sentencia favorable en sede constitucional.

85 Barros (2008), p. 251. 
4. El recurso de protección es una vía que permite revisar la constitucionalidad de una sentencia pronunciada por un juez civil, como lo ha sostenido cierta doctrina, y según se desprende de las actas de la comisión constituyente.

5. Las objeciones doctrinarias y jurisprudenciales respecto de esta procedencia decaen frente a la fuerza que debe primar en la defensa de los derechos constitucionalmente garantizados, debiendo prevalecer frente a la existencia eventual de otras vías ordinarias para lograr la misma tutela, de la posible infracción al principio de cosa juzgada, o la afectación de la ritualidad del proceso. Asimismo, la doctrina y jurisprudencia han asumido erróneamente en muchos casos que una sentencia ha respetado la Carta Fundamental por el solo hecho de pronunciarse en un proceso judicial.

6. El recurso de protección resulta una vía idónea para controlar la constitucionalidad de las sentencias civiles en que se cometan irregularidades o arbitrariedades de carácter grave y notorio, siendo el ejemplo más evidente, y de mayor ocurrencia práctica, las sentencias que afectan a terceros que no han sido parte en el juicio en que se pronunció, y que han quedado en indefensión respecto de sus efectos.

7. La sentencia que acoge un recurso de protección respecto de una ilegalidad cometida en una sentencia civil tiene efecto de cosa juzgada respecto de la sentencia misma que se pronuncia sobre el fondo del asunto.

8. La jurisprudencia de los últimos veinticinco años ha reconocido la procedencia del recurso de protección como vía de impugnación de las sentencias civiles en que se han cometido graves vulneraciones constitucionales, en especial, en los casos en que se ha afectado a terceros que han quedado en indefensión.

\section{BiBLIOGRAFÍA CITADA}

Aldunate, Eduardo (2007), "La reforma constitucional del año 2005 desde la Teoría del Derecho y la Teoría de la Constitución”, en Revista de Derecho Público, 69 de año 2007.

(2010): "La acción de inaplicabilidad: ¡control concreto?", en La Semana Juridica, Edición Especial.

Alexy, Robert (2013): El concepto y la validez del derecho (Editorial Gedisa, España).

Atienza, Manuel (2013): Curso de argumentación jurídica (Editorial Trotta, España).

Atria, Fernando (2005): "Proceso civil. Comentario a la jurisprudencia del año 2004”, en Revista de Derecho de la Universidad Adolfo Ibáñez (No 2, 2005). 
Aylwin, Patricio (2009): El juicio arbitral (Editorial Jurídica de Chile).

BARROS, Enrique (2008): Tratado de Responsabilidad Extracontractual (Editorial Jurídica de Chile).

Bordalí, Andrés (2007): "La unidad en la interpretación jurisdiccional de los derechos fundamentales: una tarea pendiente en el derecho chileno", en Revista chilena de Derecho de la Pontificia Universidad Católica de Chile (vol. 34, número 3, septiembre-diciembre de 2007).

CARrera, Liliana (2011): "La acción de tutela en Colombia”, en Revista del Instituto de Ciencias Jurídicas de Puebla (Colombia, año V, No 27. Enero-junio 2011).

CARRETTA, Francesco (2013): La coherencia en el proceso civil. Imperativo conductual $y$ decisional desde la buena fe (casos y jurisprudencia) (Editorial LegalPublishing Thomson Reuters, Santiago de Chile).

Cazor, Kamel y Pica, Rodrigo (2009): "Tribunal Constitucional y control concreto en Chile: ¿evolución hacia un amparo imperfecto?”, en Revista Nomos, Universidad de Viña del Mar (No 3, 2009).

De La Oliva Santos, Andrés (2005): Objeto del proceso y cosa juzgada en el proceso civil (Editorial Thomson Civitas, Navarra, España).

Delgado, Jordi (2012): "El recurso extraordinario en el proyecto de Código Procesal Civil", en Revista Ius et Praxis de la Universidad de Talca (Año 18, № 2).

DwORKIn, Ronald (2012a): El imperio de la justicia (Gedisa Editorial, Barcelona, España).

(2012b): Los derechos en serio (Ariel Derecho, Barcelona, España).

FernÁndeZ, Francisco (2005): "El recurso de amparo en España", en Revista Jurídica Brasília (v. 7, n. 74, agosto-septiembre de 2005. Contenido disponible en http://www.planalto.gov.br/ccivil_03/revista/Rev_74/artigos/PDF/ FranciscoSegado_Rev74.pdf).

FigueroA, Rodolfo (2014): Privacidad (Santiago, Ediciones Universidad Diego Portales).

García Barzelatto, Ana María (2013): “¿Quién es el supremo intérprete de la Constitución? Caso Gómez Montoya con Corporación Administrativa del Poder Judicial (CAPJ)", en Relaciones del Tribunal Constitucional con los demás órganos del Estado. Monografías (Miriam Henríquez y María Pía Silva coord., Editorial LegalPublishing/Thomson Reuters, Santiago de Chile).

García, José Francisco y Verdugo, Sergio (2010): "Tribunal Constitucional, certiatori y precedente", en Estudios Constitucionales. Asociación Chilena de Derecho Constitucional (Editorial Librotecnia). 
(2013): Activismo judicial, ¿hacia el gobierno de los jueces? (Santiago, Ediciones L y D).

Garrote, Emilio (2012): “Cosa juzgada constitucional sui generis y su efecto en las sentencias del Tribunal Constitucional en materia de inaplicabilidad e inconstitucionalidad", en Estudios Constitucionales de la Universidad de Talca (Año 10, № 2).

GÓMEZ, Gastón (2008): "Recurso de protección. Informe de jurisprudencia 20012006 frente a actos u omisiones cometidos por órganos del Estado para el Ministerio de Obras Públicas" (Facultad de Derecho de la Universidad Diego Portales, marzo de 2008. Disponible en http://catalogo.bcn.cl).

(2013): Las sentencias del Tribunal Constitucional y sus efectos sobre la jurisdicción común (Ediciones Universidad Diego Portales).

Hart, Herbert L. A. (1998): El concepto del Derecho (Editorial AbeledoPerrot, Buenos Aires).

Kelsen, Hans (2009): La polémica Schmitt/Kelsen sobre la justicia constitucional: El defensor de la Constitución versus ¿Quién debe ser el defensor de la Constitución? Estudio preliminar de Giorgio Lombardi (Editorial Tecnos, Madrid, España).

López Medina, Diego (2008): El derecho de los jueces (Editorial Legis, Universidad de los Andes, Colombia).

Lovera, Domingo y Ugarte, José Luis (2010): "Reglas, principios y (ahora) justicia constitucional. Cuestiones conceptuales", en Estudios Constitucionales. Asociación Chilena de Derecho Constitucional (Editorial Librotecnia).

MacCormick, Neil (2010): H. L. Hart (Editorial Marcial Pons, Barcelona, España).

MARín, Juan Carlos (2014): Las medidas cautelares en el proceso civil chileno. Doctrina, jurisprudencia y Derecho comparado (Editorial Jurídica de Chile).

Mosquera, Mario y Maturana, Cristián (2010): Los recursos procesales (Editorial Jurídica de Chile).

NiEVA, Jordi (2003): El recurso de casación civil (Ariel Derecho, Barcelona). (2006): La cosa juzgada (Atelier Libros, España).

(2010): El recurso de casación (Editorial AbeledoPerrot-Legal Publishing. Santiago, Chile).

NúÑEZ, José Ignacio (2012): "Constitución, neoconstitucionalismo y lagunas jurídicas (normativas y axiológicas)", en Estudios Constitucionales de la Universidad de Talca (Año 10, No 2). 
NúÑEZ, Manuel (2008): "El control de la igualdad en la aplicación de la ley como factor de expansión del control concreto de constitucionalidad de las leyes", en Sentencias destacadas 2007. Una mirada desde la perspectiva de las politicas públicas (Libertad y Desarrollo, Santiago de Chile).

(2012): "Los efectos de las sentencias en el proceso de inaplicabilidad en Chile: examen a un quinquenio de la reforma constitucional", en Revista Estudios Constitucionales de la Universidad de Talca (Año 10, No 1, 2012).

OrTÚZAR, Waldo (1994): "El recurso de protección y las resoluciones judiciales" (Colegio de Abogados de Chile, diciembre de 1994).

Paredes, Felipe (2012): La garantía jurisdiccional de los derechos fundamentales en el ordenamiento jurídico chileno. Tesis Doctoral Universitat Pompeu Fabra, Barcelona. Contenido disponible en http://repositori.upf.edu/ handle/10230/17086

Pfeffer, Emilio (2011): "La inaplicabilidad, ¿un seudoamparo de derechos fundamentales?, en Estudios sobre justicia constitucional. Libro homenaje a la profesora Luz Bulnes Aldunate (Editorial Jurídica de Chile, 2011).

PicA, Rodrigo (2010): “¿En qué consiste el denominado "control concreto de constitucionalidad" y en qué medida la acción de inaplicabilidad por inconstitucionalidad de la ley participa de dicha caracterización?”, en Estudios Constitucionales. Asociación Chilena de Derecho Constitucional (Editorial Librotecnia).

Pozo, Nelson (2008): Las nulidades (Editorial Punto Lex, Santiago).

Romero, Alejandro (2003): "La improcedencia de la acción de nulidad de Derecho público para revisar resoluciones judiciales, como precedente judicial", en Revista Chilena de Derecho, No 30, 2003.

(2004): La jurisprudencia de los tribunales como fuente del Derecho. Una perspectiva procesal (Editorial Jurídica de Chile).

(2011): La cosa juzgada en el proceso civil chileno. Doctrina y jurisprudencia (Editorial Jurídica de Chile).

(2012): "La sentencia judicial como medio de prueba", en Revista Chilena de Derecho, vol. 39, No 2, año 2012.

(2014): Curso de Derecho procesal civil. La acción y la protección de los derechos (Santiago, Editorial Legal Publishing). 
SALAS, Julio (1990): "El recurso de protección y las decisiones judiciales", en Revista de Derecho de la Universidad de Concepción (No 187, año LVIII, enero-junio 1990).

SeArle, John (2009): Actos del habla (Editorial Cátedra, Madrid, España).

SERRA, Manuel (2008): Jurisdicción, acción y proceso (Editorial Atelier, Barcelona, España).

SiLva, Luis Alejandro (2010): "Las garantías judiciales de los derechos fundamentales como garantías de la legalidad", en Estudios Constitucionales. Asociación Chilena de Derecho Constitucional (Editorial Librotecnia).

(2012a), “¿Es el Tribunal Constitucional el supremo intérprete de la Constitución?”, en Revista de Derecho de la Pontificia Universidad Católica de Valparaiso (XXXVIII, 2012).

(2012b): "La constitucionalidad del artículo 102 del Código Civil ante el Tribunal Constitucional. Comentario crítico del requerimiento de inaplicabilidad fallado en la sentencia rol No 1881, de 3 de noviembre de 2011", en Revista Ius et Praxis de la Universidad de Talca (Año 18, № 1).

Soto-Kloss, Eduardo (1982): El Recurso de Protección, Orígenes, Doctrina y Jurisprudencia (Editorial Jurídica de Chile).

Trujillo, Mariella (2003): "El derecho a la tutela judicial efectiva y el amparo constitucional contra resoluciones judiciales: diferencias y semejanzas entre la legislación peruana y la legislación española”. La Constitución y su defensa (algunos problemas contemporáneos), en Revista del Instituto Iberoamericano de Derecho Constitucional (Editorial Jurídica Grijley, Perú).

VEGA, Francisco y ZúNIIGA, Francisco (2006): "El nuevo recurso de inaplicabilidad por inconstitucionalidad ante el Tribunal Constitucional. Teoría y práctica”, en Revista Estudios Constitucionales de la Universidad de Talca (noviembre de 2006).

VIERA, Christian (2012): “La Corte y el Tribunal ¿Quién vela por la Constitución? Comentario a propósito de la sentencia de la Corte Suprema rol No 45182011, que rechaza el recurso de protección interpuesto contra la Corporación Administrativa del Poder Judicial", en Revista de Derechos Fundamentales, Universidad de Viña del Mar (No 7, 2012).

VON MÜNCH, Ingo (1979): "El recurso de amparo constitucional como instrumento jurídico y político en la República Federal de Alemania”, en Revista de Estudios Políticos del Centro de Estudios Políticos y Constitucionales (España, No 7, 1979). 
Von Wright, Georg Henrik (1997): "Ser y deber ser". La normatividad del derecho (Aulis Aarnio y otros editores) (Editorial Gedisa, Barcelona, España).

WitTGenstein, Ludwig (2012): Investigaciones filosóficas (Editorial Crítica, Barcelona, España).

\section{JURISPRUDENCIA CITADA}

Caillaux y otro (1994): Corte Suprema, de 28 de enero de 1994 (apelación de recurso de protección), en Informe constitucional No 779, de 27 de abril de 1994.

Banco de Santiago (1994): Corte Suprema, de 19 de julio de 1994 (apelación de recurso de protección), en Informe constitucional No 839 de 1994.

Sociedad Agroindustrial Blanqueado (1996): Corte Suprema, rol No 1360-1996, de 28 de mayo de 1996 (apelación de recurso de protección).

Forestal Cholguán S. A. (1997): Corte Suprema, rol No 1933-1997, de 7 de enero de 1998 (apelación de recurso de protección).

Ramírez Necochea (1997): Corte Suprema, rol No 2155-1997, de 15 de diciembre de 1997 (apelación de recurso de protección).

Municipalidad de Arica (1997): Corte de Apelaciones de Arica, rol No 5670-1997 de 10 de septiembre de 1997; Corte Suprema, rol No 3286-1997, de 10 de septiembre de 1997.

Adriana Vinet (1998): Corte de Apelaciones de Concepción (recurso de protección), rol No 216-1996, de 7 de septiembre de 1998.

Patricia Wohlk (2002): Corte de Apelaciones de Concepción, rol No 3743-2001, de 28 de junio de 2002 (recurso de protección); Corte Suprema, rol No 25502002, de 1 de octubre de 2002 (apelación).

Edwin Wohlke (2003): Corte de Apelaciones de Puerto Montt, rol No 40782003, de 3 de diciembre de 2003 (recurso de protección); Corte Suprema, rol No 5570-2003, de 27 de enero de 2004 (apelación).

Inversiones Metalpar S.A. (2003): Corte de Apelaciones de Concepción, rol No 826-2003 (recurso de protección); Corte Suprema, rol No 4126-2003, de 16 de octubre de 2003 (apelación).

Henríquez Japke (2003): Corte de Apelaciones de Puerto Montt, rol No 3727 2003, de 10 de marzo de 2003 (recurso de protección); Corte Suprema, rol No 1074-2003 de 16 de abril de 2003 (apelación). 
Rolf Eicher (2004): Corte de Apelaciones de Puerto Montt, rol No 156-2004, de 30 de junio de 2004 (recurso de protección); Corte Suprema, rol No 29112004, de 13 de septiembre de 2004 (apelación).

Juan Giacaman y Compañía Limitada (2004): Corte de Apelaciones de Concepción, rol No 558-2004, de 23 de agosto de 2004 (recurso de protección); Corte Suprema, rol No 3973-2004, de 23 de noviembre de 2004 (apelación).

Sindicato de Trabajadores Catedral (2005): Corte Suprema (recurso de revisión), rol No 2372-2005, de 19 de enero de 2005.

Pedro Vera Parra (2006): Corte de Apelaciones de Puerto Montt, rol No 1422006, de 21 de septiembre de 2006 (recurso de protección); Corte Suprema, rol No 5070-2006, de 30 de octubre de 2006 (apelación).

Daniel Medina Berrocal (2009): Corte de Apelaciones de Valdivia, rol No 3132009, de 24 de junio de 2009 (recurso de protección).

Paula Anguita Ramírez (2008), rol No 2008-2008, de 27 de junio de 2008 (recurso de protección); Corte Suprema, rol No 4135-2008, de 11 de septiembre de 2008 (apelación).

Mirna Sepúlveda Arias (2008): Corte de Apelaciones de Talca, rol No 165-2008, de 23 de septiembre de 2008 (recurso de protección).

Magaly Contreras Romo (2008): Corte de Apelaciones de Punta Arenas, rol No 77-2008, 13 de noviembre de 2008 (recurso de protección).

Carlos Ominami (2009): Tribunal Constitucional, rol No 1182, de 16 de abril de 2009 (inaplicabilidad por inconstitucionalidad).

Claudia Nogueira Fernández (2009): Corte de Apelaciones de Santiago, rol No 9522-2008, de 31 de marzo de 2009 (recurso de protección).

Gaete González (2010): Tribunal Constitucional, rol No 1438, de 7 de septiembre de 2010 (inaplicabilidad por inconstitucionalidad).

Cortés Zamora (2010): Tribunal Constitucional, rol No 1437, de 7 de septiembre de 2010 (inaplicabilidad por inconstitucionalidad).

Rosemarie Weber Paulus (2010): Corte de Apelaciones de Valparaíso, rol No 1482010, de 29 de abril de 2010 (recurso de protección).

Gómez Montoya (2011): Tribunal Constitucional, rol No 1801 de 12 de abril de 2011 (inaplicabilidad por inconstitucionalidad).

Papelera Nacional Limitada (2013): Corte de Apelaciones de Santiago, rol No 34252-2012, de 21 de enero de 2013 (recurso de protección). 
Sociedad Maderera Vásquez Hermanos Limitada (2013): Corte de Apelaciones de Valdivia, rol No 1193-2013, de 5 de agosto de 2013 (recurso de protección). Luis González del Valle (2014): Corte de Apelaciones de Concepción, rol No 18622014, de 7 de mayo de 2014 (recurso de protección).

Constructora Luis Navarro S.A. (2014): Corte de Apelaciones de Talca, rol No 938-2014, de 7 de julio de 2014 (recurso de protección).

\section{NORMAS JURÍDICAS CITADAS}

Constitución Política de la República

Código Orgánico de Tribunales 